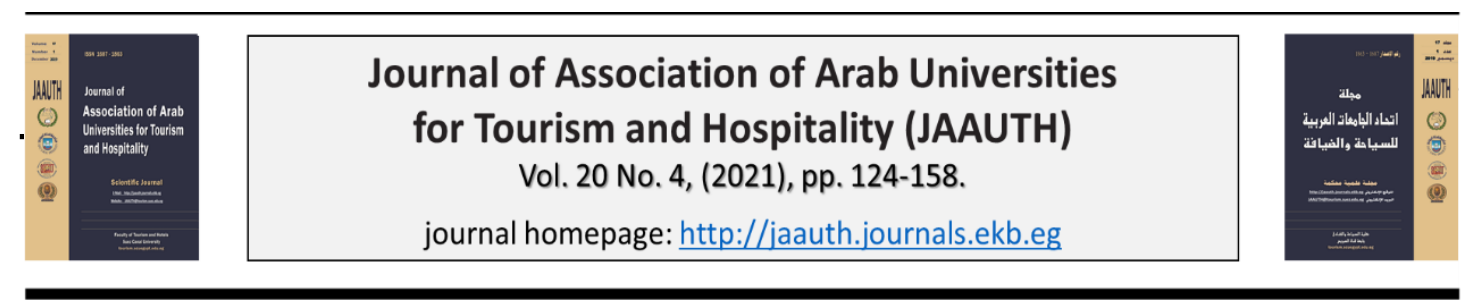

\title{
Boats Representation in the Byzantine Art
}

\section{Mofida EI Weshahy Sarah Maher Halim}

Tourism Guidance, Faculty of Tourism and Hotels, Suez Canal University

\section{ARTICLE INFO ABSTRACT}

Keywords:

Coptic art; Byzantine, Boats; Bagawat; Kom Abu Billou; Nilotic.

\section{(JAAUTH) \\ Vol. 20, No. 4, (2021), PP. 124-158.}

For thousands of years ago, people have been using boats and ships to navigate the sea, which had attracted them to discover it's secretes. People sailed for the sake of discovery as a type of adventure, settlement, trade, and conquest. In Egypt, the Nile River was the most significant catalyst that helped in flourishing the different watercraft's industry. Since the Pre-dynastic period, they started to make their first primitive watercraft, representing it on rocks, pottery and walls, and their interest with the boats reached its burial. The boats importance had increased, and its industry became more skillful, passing through the different dynastic periods of the ancient Egyptian civilization, Ptolemaic, Greek, and Roman periods, till reaching the Byzantine Period in which the boat's representation had gained more symbolism aligned with the new Christian religion. This research aims to focus light on the boats and its uses from the Pre-dynastic till the Byzantine Periods, to analyze different scenes representing boats through this period, to trace the development of the scenes representing boats from ancient egyptt till the Byzantine period, and to determine the boat's symbolism in Coptic art.

\section{Introduction}

The ancient Egyptian civilization was characterized by the evolution of many cultures raised along the Nile River since the Prehistorical periods (Fig.1) ${ }^{1}$, these cultures had their own style in art and creativity. Through examining the monuments and artifacts left by the early civilizations, one could find that the boats' representation was one of the most favorite topics in art, being represented on rocks, walls of the tombs and temples since 8000 B.C. More than 20 species have been found that provide evidence of the ancient Egyptians' interest in it ${ }^{2}$.

\footnotetext{
${ }^{1}$ M. Isler, Sticks, Stones and Shadows, Building the Egyptian Pyramids, University of Oklahoma Press, 2001, fig 2.1.

2 J. Vandier, Manuel d'archeologie Egyptienne, Les époques de formation, Tom I, Paris, 1952, p. 209-

211, fig. 267, 274, 275.
} 
The ancient Egyptian texts reflected many words expressing the meaning of boats or

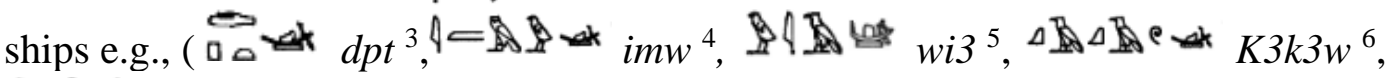
( 1 i $h c w^{7}$ ) according to its uses, while the boat's supervisor named $m s y$ - $d p t^{8}$.

- Solar boat Pli ek wi3 ${ }^{9}$.

- Abydos sacred boat $\square s m t 10$.

- Skr bark l-o hnw 11 .

- Sacred boat, the $\stackrel{\text { 近 }}{\longleftarrow}$ wi3 nfrw ${ }^{12}$, and dpt ntr the divine bark ${ }^{13}$.

- Sailboats 㛿一进 hnti 14 .

- Morning boat: $\cong$ "

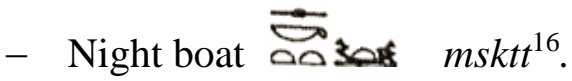

The simple boats made of papyrus and plant materials, were considered among the man's fist trials since the Early Neolithic Badarian Culture 4500-4000 B.C., which is contemporary with Neolithic Helwan culture, El Omari and El Mostagadda. Followed by the Chalcolithic Period 4000-3500 B.C., contemporary with the Amratian, El Hamamya, El- Maadi, and Naqqada I cultures, that was marked by its pottery decorations and rock inscriptions representing boats especially on the eastern mountains to the Nile. Furthermore, boat models made of burnet mud were found ${ }^{17}$.

With the Gerzean culture, contemporary with Naqqada II 3500-3200 B.C, rapid changes occurred showing a clear line of development from the early Chalcolithic Period. Different styles and topics were added to the pottery's decorations, especially

\footnotetext{
${ }^{3}$ A. Gardiner, Egyptian Grammar Being an Introduction to the Study of Hieroglyphs, $3^{\text {rd }}$ edition, Griffith Institute, Oxford, 1957, p.22.

${ }^{4}$ Ibid, p.498. the singular boat usually stood as imw.

${ }^{5}$ Ibid, p.498, 499.

${ }^{6} \mathrm{Ibid}, \mathrm{p} .498 . k 3 k 3 w$ a word rarely used.

${ }^{7}$ Ibid, p.498.

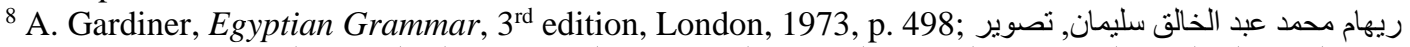
المر اكب الدينية علي المعابد المصرية في العصرين اليوناني و الروماني, رسالة ماجستير, كلية السياحة و الفنادق, الإسكندرية, 2019, ص 6

${ }^{9}$ A. Gardiner, op.cit,1957, p.22.

${ }^{10}$ Ibid, p.499.

${ }^{11}$ Ibid, p.468.

${ }^{12}$ A. Erman, Wörterbuch Der Aegyptischen Sprache, Vol IV, Leipzig, 1982, p.225; J. Bleeker,

Egyptian Festival Enactments of Religious Renewal, Leiden, Brill, 1967, p.77; ريهام محمد عبد الخالق المرجع السابق, ص 6.

${ }_{13}$ A. Gardiner,1957, p.24, p.498.

${ }^{14}$ Ibid, p.499.

${ }^{15}$ W. Budge, An Egyptian Hieroglyphic Dictionary, Vol 2, Harrison and sons, London, 1920, p. 626; ريهام محمد عبد الخالق, المرجع السابق, ص 6.

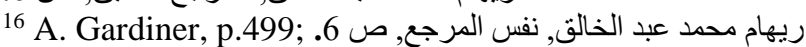

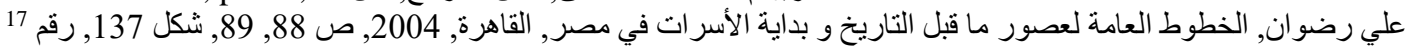
.31
} 
with the large variety of pottery excavated related to the Gerzean Period, famed by its decorations known as "the boat scenes". Its decorations included boats topped with cabins as two identical constructions displaying various emblems, the number of oars per one boat had reached 40 oar which is too many for the size of the Gerzean boat itself, in addition to some appeared with anchors (Fig.2) ${ }^{18}$. From the Unification Period $^{19}$, on the walls of Hierakonpolis Tomb no. $100^{20}$, (Proto-dynastic tomb of outstanding importance about 3500 B.C, Nakada $\left.\mathrm{II}^{21}\right)^{22}$, boats with both high and low prows in a procession scene were represented among scenes of hunting men and animals, painted in a colorful way (Fig.3) ${ }^{23}$. A similar scene represented on an ivory knife from Gebel El Arak south of Abydos and now exhibited in the Louvre Museum, in which similar boats were represented with low prow among the scenes of the battle and the predictor animals (Fig.4) ${ }^{24}$, this was beside what was left on stones and labels $(\text { Fig.5 })^{25}$.

The importance of the watercraft had increased with the Early Dynastic Periods, as its importance connected with the trade and the transportation through the Nile River from north to south and vice versa, such as transporting stones, blocks (Fig.6) ${ }^{26}$, and pottery. Moreover, its role in the funerary rituals, in transferring the deceased to the otherworld $^{27}$. From the Old Kingdom, $1^{\text {st }}$ Dynasty is a beautiful representation for a boat on a comb related to king Djet, which is considered the earliest surviving depiction of the God Seker's bark ${ }^{28}$, now preserved in the Egyptian Museum JE47176 $(\text { Fig. } 7)^{29}$.

Excavation at Abydos had brought to light fourteen boats known as Abydos boats. They were located alongside the massive mudbrick structure known as Shaunet El

\footnotetext{
${ }^{18}$ F. El-Yahky, "Clarifications on the Gerzean Boat Scenes", BIFAO 85 (1985), p. 187- 195, pl. xxxiii, xxxiv; M. Isler, Sticks, Stones and Shadows, Building the Egyptian Pyramids, University of Oklahoma Press, 2001, p.42, fig. $2.3 \mathrm{r}$.

${ }^{19}$ At a period approximately 3400 B.C., the country had passed from the Neolithic culture to two more well organized monarchies one comprising the Nile valley and the other comprising the Delta valley, this accompanying developments in art and architecture. W.B. Emery, Archaic Egypt, London, 1961, p. $38,39$.

${ }^{20}$ Hierakonpolis is the name known during the Greek period which means the falcon's city, and in ancient Egypt known as Nekhen nhn, means Horus with the falcon's head. It is said to be the first

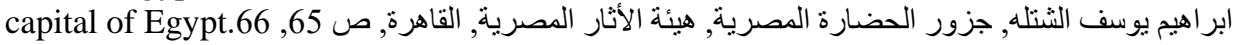

${ }^{21}$ Its discoverer termed it prehistory, while other historians related it to late Gerzean (Naqada II). H. Case and J.C. Payne, "Tomb 100: The Decorated Tomb at Hierakonpolis", The Journal of Egyptian Archaeology, Vol. 48 (Dec. 1962, p. 5, pl.1 a, b.

22 J.E. Quibelle and F.W. Green, Hierakonpolis, Part II, London, 1902, PL. LXVII; H. Case and J.C. Payne, Op.cit, pl.1 a.b; . علي رضوان, المرجع السابق, ص 100؛ ابر اهيم يوسف الثنله, المرجع السابق, شكل

${ }^{23}$ J.E. Quibelle, op.cit, PL. LXVII

${ }^{24}$ W.B. Emery, Archaic Egypt, London, 1961, fig. 1.

${ }^{25}$ Ibid, p.50, fig.12, 20, 22; M. Isler, op.cit, p. 46, Fig. 2.5, 2.6.

${ }^{26}$ E. Strouhal, Life of the Ancient Egyptians, University of Oklahoma Press, London, 1992, P. 178, no. 193.

${ }^{27}$ Ch. Ward, “Ships and Shipbuilding”, OEAE, Vol.3 (2001), p. 281; ريهام محمد عبد الخالق سليمان, المرجع السابق, ص

${ }^{28}$ Skr bark $l \leq 0$ hnw. A. Gardiner, op.cit, 1957, p.468.

${ }^{29}$ W.B. Emery, op.cit, p. 248, fig. علي رضوان, المرجع السابق, ص 169.؛ 146 .
} 
Zebib, attributed to the $2^{\text {nd }}$ Dynasty, reign of king Kha-sekhem-wy ${ }^{30}$. The boat grave cemetery at Abydos has provided the world vivid evidence for the way of early Egyptian wooden boats' building, as part of the First Dynasty funeral monument at Abydos $^{31}$.

From the Old Kingdom several funerary boats were excavated around the pyramid complexes, returns to $4^{\text {th }}-6^{\text {th }}$ dynasty. One of the masterpieces related to the $4^{\text {th }}$ Dynasty, is king Khufu's solar boat. In 1954 a boat pit was discovered just south the base of the great pyramid in Giza, it was found disassembled into pieces, and reinstalled. This boat is considered the oldest, largest, and best-preserved described as "a masterpiece of woodcraft", now preserved in Giza Solar Boat Museum (Fig.8) ${ }^{32}$.

The boat's industry and representation continued in development during the Middle and New Kingdoms, either represented on the walls of tombs and temples, or left as huge models. Among the best examples left related to the Middle kingdom are Dahshour boats; in which five boats were found to the southern side of Senwosret III's pyramid inside the enclosure wall and three boats outside the wall ${ }^{33}$.

What was impressive in the study related to the Middle Kingdom $12^{\text {th }}$ Dynasty, is what was revealed through the excavations at Abydos between 2014-2016, a boat pit returned to the reign of Senwosret III. The most remarkable feature in this excavation what is known as "the boat tableau" which is a number of 120 drawings of watercrafts incised on the interior walls of the boat building with total length $25 \mathrm{~m}$, not in the form of one scene but a random graffiti, that vary in size and complexity. At the upper end are large, well-rendered boats depicted with masts, sails, cabins, rudders, and oars. While at the lower end of the range are highly simplified boats, rendered as one or two curving lines (Fig.9) ${ }^{34}$.

During the New Kingdom, the boats appearance had become a part of the tombs and temples decorations, represented in the Nilotic scenes e.g., the tomb of Nakht and Menna reign of Tuthmosis IV (Fig.10) $)^{35}$, or as a main part in the funerary ritual scenes. Mentioning boats and ships during the New Kingdom, it is inevitable to mention the ships used by the queen Hatshepsut during her journey to the lands of Punt depicted on the walls of her temple in Deir El Bahari (Fig.11) ${ }^{36}$. Furthermore,

\footnotetext{
${ }^{30} \mathrm{Ch}$. Ward, "Boat-building and its Social Context in Early Egypt", Interpretations from the First Dynasty Boat-Grave Cemetery at Abydos, 2006, p. 118; D. O' Corner, Abydos, Egypt's First Pharaohs and Cult of Osiris, AUC Press, 2009,183-188; J.W. Wegner, "Abydos", The Oxford Encyclopedia of Ancient Egypt, D.B. Redford (ed.), Vol I, Oxford University Press, New York, 2001, P.9.

${ }^{31}$ Ch. Ward, Boatbuilding, op.cit, p.118.

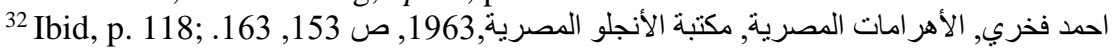

3. P. Creasman, “An Exploratory Geophysical Survey at the Pyramid Complex of Senwosret III at Dahshur", the International Journal of Nautical Archaeology (2009)38.2, pp. 386-399.

${ }^{34}$ J. Wegner, "A Royal Boat Burial and Watercraft Tableau of Egypt's 12 ${ }^{\text {th }}$ Dynasty (c.1850 BCE) at South Abydos", The International Journal of Nautical Archaeology, no. 46, 2017, p. 5-30, fig. 11.

35 A. Siliotti, Guide to the Valley of the Kings, New York, 1997, p.155.

${ }^{36}$ F. Monderson, Hatshepsuts Temple at Deir El Bahari, Bloomington, 2007, p.33.
} 
the fleet appeared in the naval battle between Ramses III against the Sea People recorded in Medinet $\mathrm{Habu}^{37}$ (Fig.12) ${ }^{38}$.

With the Late Period and Early Ptolemaic Era, the boats' appearance continued in the same way with the same uses as before (Fig.13) ${ }^{39}$, reaching the Greco-Roman Period, where the boat's industry reached its perfection due to the wide spread of their trade. It continued in appearance with all its previous uses in the Greco- Roman Temples and on artifacts with the Egyptian style ${ }^{40}$. one of the most famous ships related to that period, is the ship Argo that took the sailors to Colchis, searching for the golden fleece, it had a group of young Greeks headed by Heraclius. The name Argo may be taken from the Greek word means agile or named after its builder $\operatorname{Argus}^{41}$ (Fig.14) ${ }^{42}$.

Different watercraft kept up in appearance in art with the Byzantine period, despite less or limited in comparison with the previous periods, but it gained more symbolism and different meanings as will be discussed in detail. Boats were mentioned in the Coptic language by more than one name E.g., kdTod means boat or skiff ${ }^{43}$, KIBütoc means (Noah's Ark, Box, Chest) ${ }^{44}$ as inscribed above Noah's Ark in the chapel of Exodus at El Bagawat (Fig.15), cKaфoc small boat or ship ${ }^{45}$ and $6 I N O \gamma \omega 2 \epsilon$ means fishing boat, ${ }^{46}$.

\section{The Boat's symbolism in Coptic Art}

The symbol in the language means the sign or the form of verbal and non-verbal expression, through which the human mind can accept the meaning and use it to hide specific meanings or draw concepts that may be difficult to explain. Some thinkers defined symbols as the art of thinking through images or may be an event e.g., Isaac's Sacrifice. Christian symbols have been used to express the culture of the Egyptian society in a consistent way through the Coptic art ${ }^{47}$.

In Coptic art the boat or the ship had gained an additional importance through its symbolism, it was one of the most important Christian symbols used by them. It

\footnotetext{
${ }^{37}$ Medinet Habu is the modern name of the southern area of the Theban necropolis, its name may be token from the name of the temple of Amenophis son of Hapu. A. El Mahdy, K. El Bassiiouny and M. El Weshahy, "Scenes of the Goddess Amounet in the Temple of Medinet Habu", JAAUTH (15), 2018, P. 40.

${ }^{38}$ H. Nelson, Madinet Habu, Earlier Historical Records of Ramses III, vol. I, the University of Chicago Press, Chicago, 1930, pl.37.

39 W. Omran, "Transporting the Deceased by the Wheeled Cart in the Greco-Roman Tombs", JAAUTH, Vol.17, no.2, (2019), pl.1.

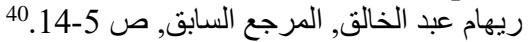

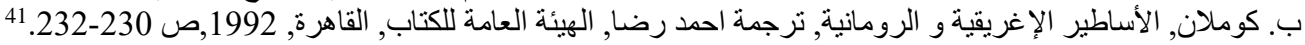

${ }^{42}$ S. Souli, Greek Mythology, Athens, 1995, p. 97.

${ }^{43}$ A Basic Coptic Dictionary, Alphabetum Lactobiatarum, (ed.) Hermit of the Hermits of saint Bruno, St. Mary's Hermitage Press, 2014, кaтod.

${ }^{44}$ Ibid, KIBütoc.

${ }^{45}$ Ibid, cKaфоc.

${ }^{46} \mathrm{https} / / /$ coptic-dictionary.org/

عزت زكي حامد قادوس و محمد عبد الفتاح السيد, الأثار القبطية و البيزنطية, الإسكندية, 2002, ص240.47
} 
accompanied with the symbolism of the Church, that transports the believers to the desired land of safety. At the same time symbolizes to the desired paradise. Moreover, used as a symbol of salvation through which Noah and the believers survived ${ }^{48}$. Noah's ark may be also used as a symbol to Baptism ${ }^{49}$. The church is symbolizing to the monk himself, who crosses through it to the spiritual world he seeks ${ }^{50}$. In other way, it can be said it symbolizes to the church, and the safe life journey ending in the harbor of peaceful death ${ }^{51}$. When the boat is represented surrounded with Alpha and Omega letters (the beginning and the last) it symbolizes the whole universe, a representation repeated on tombstones ${ }^{52}$. Also, the boat's Anchor symbolizes to the hope in survive and salvation ${ }^{53}$.

\section{II-The Boat's Importance in the Old and New Testaments Stories and in Monasticism}

The most significant mentioning of the boats or ships in the Old Testament are through the story of Jonah, the story of Noah. Also, from the Old Testament it was known that Solomon was the first to use the commercial ships (1Kings 5:9). In the New Testament stories, it appeared through the story of the disciple's choice and calming the wind (Math 8:25), (Marc 4:38), (Lu 8:24), and used by the Christ in teaching the people from the boat of Simon ( $\mathrm{Lu} \mathrm{3:5).}$

Boats were used by the Holy Family through their journey into Egypt in passing from Khast or Sakha (Coptic cbwor) ${ }^{54}$ modern Kafr El Sheikh to Desouk, as they crossed the Rosetta Nile branch by a boat. Furthermore, after staying few days in Babylon they moved to a region known as Ma'adi and took a boat to cross to Giza (the old capital of Memphis) MENB€ or m€qI in Coptic 55 "nuf "in the Holy Bible ${ }^{56}$.

Boats had a great role in monastic life especially with the Pachomian system, it must be remembered that it built its monasteries on the greenbelt of the Nile, conducted business outside the monastery. They retained their own boats for travel up and down the Nile, its uses became more obvious when one turns to tax lists, contracts, and shipping papers e.g., a document has brought to light included reports on tax paid by a monk named Tabennesiote ${ }^{57}$.

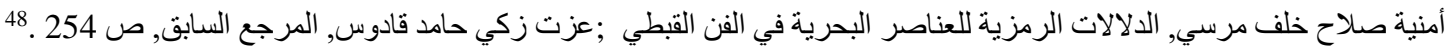

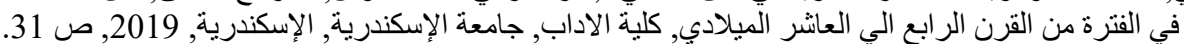

${ }^{51}$ F.A. Hooper, Funerary Stelae from Kom Abou Billou, Kelsey Museum of Archaeology, 1961, p. 1-3; G. Gabra and M.E. Krauss, the Treasures of Coptic Art in the Coptic Museum and Churches of Old Cairo, the American University in Cairo Press, p.49, no.32.

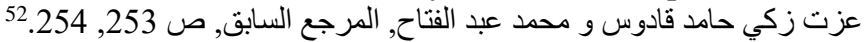

${ }^{53}$ C. Diehl, L'art Chrétien primitive et l'art Byzantine, Paris, 1929, p. 7.

${ }^{54}$ J. Maspero et G. Weit, "Matériaux pour Servir à la Géographie de 1 Égypte”, MIFAO 36, le Caire, 1919, p. 103.

${ }^{55}$ Ibid, p. 199.

ميخائيل مكسي اسكندر, المسيح في مصر الأحداث و التقاليد والأماكن المتعلقة برحلة العائلة المقدة الي الديار المصرية, الموسوعة 56 مك 55

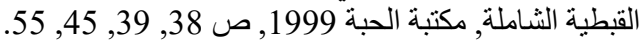

${ }^{57}$ J. E. Goehring, "New Fronteries in Pachomian Studies", the Roots of Egyptian Christianity, B.A. Pearson and J.E. Goehring (ed.), Fortress Press, New York, 1986, p. 250.
} 


\section{III-The Boats in Coptic Art}

The Coptic artist used to represent boats either among the daily life scenes, religious stories, or to represent a specific symbolism. From El Bagawat chapels $3^{\text {rd }} / 5^{\text {th }}$ century ${ }^{58}$, boats are intensively represented. Also, examples found in the Monastery of the Apa Jeremiah in Saqqara and the Monastery of St. Apollo in Bouit. Moreover, the Syriac monastery is now carried out architecturally from outside in the form of a ship from outside ${ }^{59}$, and the ceiling of the Hanging church in Old Cairo takes the shape of the ship in reference to Noah's Ark. Furthermore, archeologists found several boats in the region of Kellia ${ }^{60}$ and wall paintings representing simple boats ${ }^{61}$. This was beside its appearance on artifacts. In other way it can be said that it played a crucial role in the religious imagery specially with the funeral beliefs and in daily life needs.

\section{III.a-Boats on walls from the Necropolis of El- Bagawat in Kharga Oasis}

Doc.1: Early examples of boats came from the necropolis of El Bagawat in Kharga oasis $3^{\text {rd }} / 5^{\text {th }}$ century. From the chapel of Exodus no. (30) more than one example was found. Facing its entrance, is a simply drawn boat, in which its prow and stern are raised and turned over till they meet at the top, containing two cabins, where a woman came out from the left cabin while a man bending on the boat's right edge towards a pigeon holds a small branch in her beak. The scene representing the story of Noah and his Arc (Fig.15), and this was proofed through the writings that were over the cabins until a few years ago; кІвштоC means (Noah's Ark) ${ }^{62}$ and N $\omega \epsilon$ means (Noah) but unfortunately the writings are demolished now ${ }^{63}$.

Doc.2: Moreover, from the same chapel near one of its corners, is a more detailed boat as a part of Jonah's story. The boat represented here has high similar prow and stern, two paddles and a sail. Inside the boat are five men; one of them is controlling a paddle and the other one holding one of the sail's robes while two men are throwing

\footnotetext{
${ }^{58}$ El Bagawat cemetery located in the northern part of Kharga oasis on the southernmost slope of Gebel el Teir, near ancient Hibis and it was the burial place for the city of Hibis, it comprises more than 260 mud brick funerary chapels, returns to the late Third and early Fourth Century. Visitors have left their names and paintings on the walls of the chapels for centuries. Most of its excavations carried out by Prof. Ahmed Fakhry. G.H. Minaglou, "Architecture at al Bagawat Cemetery": Christianity and Monasticism in Alexandria and the Egyptian Deserts, G. Gabra (ed.), Cairo, 2020, p. 267, 268; J.V. Der Vliet, "Places of Passage, the Christian Epigraphy of the Western Oases with a Focus on the Kharga Oasis": Christianity and Monasticism in Alexandria and the Egyptian Deserts, (ed.) G. Gabra, Cairo, 2020, p.182.

عزت زكي حامد قادوس, المرجع السابق, ص 253.

${ }^{60}$ Kellia is one of the most celebrated monastic groupings in Lower Egypt. Its location is uncertain but according to archeologists, they believed to be the exact location of the ancient Nitria. The site is at the entrance to the Libyan desert, $18 \mathrm{~km}$ south of al-Barnuji, the ancient Nitria, two miles beyond the Nubariyyah canal. A. Guillaumont, "Kellia", CE, 1396b-1410a.

أمنية صلاح خلف , المرجع السابق, ص 30.

${ }^{62}$ A Basic Coptic Dictionary, кІвштос.

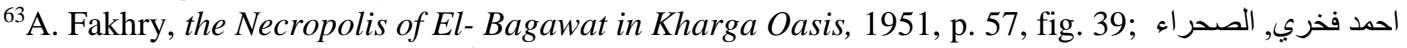

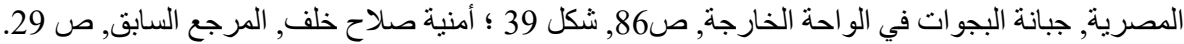


Jonah. The boat here is closely resembling the ancient Egyptian boats (Fig.16) ${ }^{64}$. The scene dates to $3^{\text {rd }} / 4^{\text {th }}$ century ${ }^{65}$.

Doc.3: From the same chapel, later additions were added by some of the visitors as a trial to imitate the main drawings. Two boats were drawn in red color in a primitive form (Fig.17a, b) ${ }^{66}$, like that represented in the story of Noah and Jonah with the addition of crosses with four equal sides and looped $\operatorname{crosses}^{67}$. The boat to the right side has two oars and a cabin filled with items, while the second one to the left has a sail and two men; one of them seems to be holding its oars.

Doc.4: Reaching Chapel of Peace no. (80), an exceptional boat is represented through the story of Noah, in which the boat was drawn in a decorative style of painting with two Corinthian columns' capitals at each side. It has a ceiling supported by a mast instead of the sail. Inside the boat Noah and his family are standing, and the name $N \omega \in$ is written over the Ark (Fig. 18$)^{68}$. The scene dates to $4^{\text {th }} / 5^{\text {th }}$ century ${ }^{69}$.

Doc.5: Also, from Chapel no. (20) are two boats represented; one of them is a roughly drawn one and the other one is more detailed on the western wall of the same chapel, the scene dates to the $5^{\text {th }}$ century (Fig.19) ${ }^{70}$. These watercrafts seemed to be fishing ships in which men are represented in a working state throwing their fishing nets into the sea.

\section{III.b-Watercrafts on the walls of the monastery of Apa Jeremiah at Saqqara:}

The early Coptic wall paintings representing boats didn't limit on the chapels of ElBagawat but also, examples were found in the monastery of Apa Jeremiah at Saqqara and Apa apollo at Baouit.

Doc.6: From Saqqara, monastery of Apa Jeremiah a boat representation was excavated 1906/1907, on apart seemed to be from the monastery's passage but was latterly formed with its east wall as a single buttress. On one of its plastered walls someone painted a ship ${ }^{71}$, topped with three crosses on mast, the ship has seven men most of them seems to be in working, one is ascending a long ladder, another holding a rope and one is holding its oars, while the middleman is standing and opening both of his hands, after examining the whole scene it's suggested that it might be representing the story of Jonah before throwing him in the sea (?), representing him in

\footnotetext{
${ }^{64}$ A. Fakhry, op.cit, p. 59, fig. 44; C. Maria Kaufmann, Handbuch der Christlichen Archaologie, Paderborn, 1922, Abb 156; C.M, Kaufmann, Handbuch der Christlichen Archaologie, Paderborn, 1905, Abb125, p.343.

احمد فخري, جبانة البجوات, ص 91 91, شكل 44.

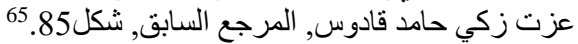

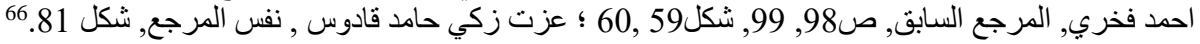

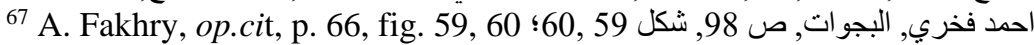

${ }^{68}$ A. Fakhry, op.cit, p. 76; C.M. Kaufmann, op.cit, 1922, Abb 152; C.M. Kaufmann, op.cit, 1905,

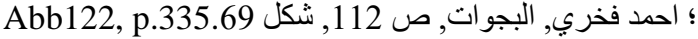

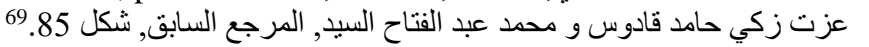

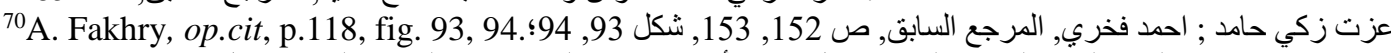

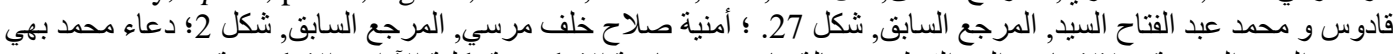

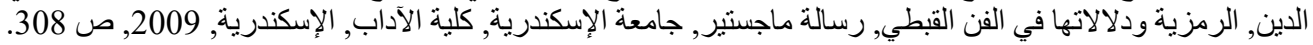

${ }^{71}$ J.E. Quibell, Excavation at Saqqara (1907-1908), le Caire, 1909, p. 13, 68, no. 782, fig.3.
} 
the middle figure praying figure or it might also be a representation of the story of calming the wind mentioned in (Math 8:25) (?).

Graffiti in Coptic was left its remained parts can be read as following.... remember [me], brother Papnoute, the monk, o God, forgive [me].... Amen, Amen (Fig.20) ${ }^{72}$.

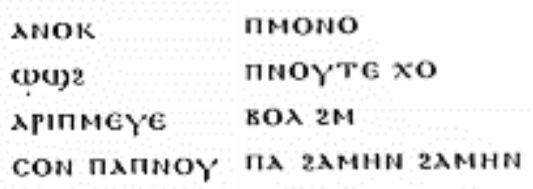

\section{III.c: Boats on the Walls of the Monastery of Apa Apollo at Baouit}

Doc.7: A simple representation came from Chapel XXXIV in the region of the monastery and necropolis of Baouit. Despite the bad state of preservation of the chapels there, but little remains of frescos decorating the walls of this construction. Many graffiti left by the pilgrims in memory of their visit; among of these graffiti left in this chapel are two boats drawn in black lines on a plastered wall, in which the one to the right side is a large, different boat with spread sails, while to the left side and below the incomplete inscriptions, is a small simply drawn boat but it is difficult to determine its details. Unfortunately, the graffiti is very mutilated (Fig.21.b) ${ }^{73}$.

Doc.8: From the same region are two graffiti left representing boats on the walls of Chapel XXXIX in the region of the monastery and necropolis of Baouit (Fig.22.a, b). This chapel is considered one of a series of adjoining constrations in the region, it was found in a very bad state of preservation, no ornaments had retained, only number of graffiti. J.Cledat had worked in the chapel among the mission of the French Institute of Archeology, and cleared some graffiti and inscriptions. What is unique is the grafitti of a large and diffirent ship, drawn in black and red paint, having small standing figures on it's back designated by the words Naүтос means the sailor, while the front inscriptions can read as following апа күрідкос пцштлптопос means father cyriaque elected for the monastery ${ }^{74}$, and two names written in charcoal below the boat геш्यргєкоүı макарєкоү ${ }^{75}$.

From examining the scene and the writings above one can suggest that it can be a ceremonial ship that might be used in celebrating the election of father Cyriaque for the monastery, or transmitted him from his country, especially its decorations and the palm branches above the cabin and its prow giving a strong indication that it was used in a ceremony.

\footnotetext{
${ }^{72}$ Ibid, p. 68 , no. 782.

${ }^{73}$ M.J. Clédat, "Le Monastère et la Nécropole de Baouit", MIFAO, 1916, p. 18-22, fig. 11.

${ }^{74}$ Father cyriaque's name was mentioned before in chapel 51 with the name of Apa Isaac and Apa Amei, according to J. Clédat their names gave information about the main cenobites who most honored the monastery. J. Clédat, "Nouvelles recherches a bouit (Houte Egypt) compagnes 1903-1904", Comptes rendus des séances de l'Académie des Inscriptions et Belles-Lettres, 48 année, N. 5, Paris, 1904, p. 526.

${ }^{75}$ M.J. Clédat, op.cit, 1916, p. 43-45, fig. 28.
} 
Moreover, on wall $\mathrm{f}$, to the left of the large bay in room XXXIX, are charcoal plots of many drawings of birds, palm trees and boats, to which are mingled the names of characters. The rest is very effaced ${ }^{76}$.

Doc.9: To the extreme left side of the entrance of chapel no. XXVI in the monastery and necropolis of Baouit, drawings were left by someone who draw a simple boat in black color and less details (Fig.23) and wrote two short lines of inscriptions ${ }^{77}$.

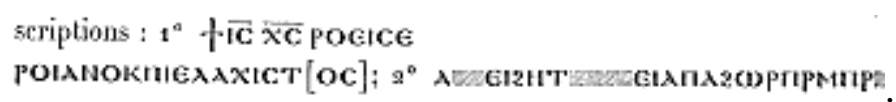

Observation: all the wall drawings representing boats appeared in places which is totally away from the Aquatic environment such as El Bagawat so what was the main reason from its representation (?)

\section{IV: Boats on Stelas:}

Boats were considered among the elements that used to be represented on stelae even before the Byzantine period, most of them came from Kom Abu Billou and few pieces were found scattered in different regions in Egypt.

\section{IV.a: Kom Abu Billou Stelae:}

In 1935 the excavations in the region of in Kom Abu Billou ${ }^{78}$, had brought to light a collection of more than two hundred stelae, dates to Late third and early fourth century, now most of them are preserved in Kelsey Museum of Archaeology of the University of Michigan in Ann Arbor. These stelae belong to the last centuries of Paganism in Egypt. Moreover, in 1970 more than 500 additional stelae were unearthed, and many coins were found having the names of the emperors which gave a clue to its approximate date ${ }^{79}$.

\section{Doc.10: Sandy Limestone Stela for a Standing Man in a Boat}

This stela is now preserved in Kelsey Museum KM21188, dates to the $2^{\text {nd }}$ quarter of the $2^{\text {nd }}$ century AD., measuring $27.2 \times 22.4 \mathrm{~cm}$. It represents a standing man (the deceased) in a prayer attitude with his two raised arms as (an orant $^{80}$ ), wearing a chiton with sleeves and a himation ${ }^{81}$ over his shoulder inside a simple papyrus skiff

\footnotetext{
${ }^{76}$ M.J. Cledat, op.cit, 1916, p.47.

${ }^{77}$ M.J. Cledat, "Le Monastère et la Nécropole de Baouit", MIFAO,1904, p. 133, 139, fig. 62.

${ }^{78}$ Kom Abou Billou is the modern name of the necropolitan site of the ancient city (Terenouthis) situated to the western edge of the delta, $70 \mathrm{~km}$ northwest of Cairo. F.A. Hooper, Funerary Stelae from Kom Abou Billou, Kelsey Museum of Archaeology, 1961, p. 1-3

${ }^{79}$ F.A. Hooper, Funerary Stelae from Kom Abou Billou, Kelsey Museum of Archaeology, 1961, p. 1-3;

G. Gabra and M.E. Krauss, the Treasures of Coptic Art in the Coptic Museum and Churches of Old Cairo, the American University in Cairo Press, p.7; Z. Hawass, Hidden Treasures of the Egyptian Museum, the American University in Cairo Press, Cairo, 2002.

${ }^{80}$ The orant in Christian iconography, is the man in prayer attitude, represented raising both of his hands upwards, and it is considered the basic gesture of prayer in the east. E. Uzukwu, Worship as Body Language, the Liturgical Press, 1997, p. 21.

${ }^{81}$ The Chiton is a simple rectangular cloth mounted on the left shoulder and leaving the right shoulder naked and might be dressed covering both shoulders while the Himation, is a loose clock with folds wore above the chiton. سلوي هنري جرجس, طرز الأزياء في العصور القديمة (فرعوني, يوناني, روماني, بيزنطي, قبطي) إنجي) مكتبة اللانجلو الدصرية, القاهرة, 2001, ص 48-53.
} 
with two paddles. On the right-side steering oar attached at the left. At the bottom between incised guidelines are two written words $\left(\mathrm{a} \Pi \mathrm{I} \omega \mathrm{N} x \mathrm{C}^{82}\right)^{83}$, means Apion 90 (Fig.24.a $)^{84}$.

\section{Doc.11: Sandy Limestone Stele for a Reclining Man in a Boat}

This limestone stela is now exhibited in Kelsey Museum KM 21190, dates to mid- $3^{\text {rd }}$ century AD, measuring $15.6 \times 20 \mathrm{~cm}$. It shows a reclining man in a papyrus skiff with a square sail propelled by the wind, resting on two pillows and holding a cup, wearing a chiton over his arm, himation wrapped around waist and draped over his left shoulder (Fig.24.b) ${ }^{85}$.

\section{Doc.12: Limestone Stela for a Squatting Man in a Boat}

A limestone stela showing a squatting man in a small boat, with upraised hands, preserved in Kelsey Museum KM21191, measuring 21.2x $25 \mathrm{~cm}$ (Fig.24.c) ${ }^{86}$. The boat represented here is very small and carved, having oars connected to its stern behind the man.

\section{Doc.13: Limestone Stela for a Reclining Man in a Boat}

This stela came from Kom Abu Billou, now preserved in Kelsey Museum of Archaeology KM21189, measuring 51x24 cm., showing a frontally depicted reclining man in a small boat wearing a chiton and himation, behind him is a standing woman with raised arms (Fig.24.d) ${ }^{87}$.

\section{Doc.14: A funerary Stela for a Man in a Bird Shaped Boat}

A piece of a limestone funerary stela representing a sailing man in a goose or swan (?) shaped sailboat, holding its oar, measuring $30 \times 20 \mathrm{~cm}$., dates to $2^{\text {nd }} / 3^{\text {rd }}$ century A.D., discovered in 1935 among the collection found in Kom Abu Billou, preserved in Kelsey Museum of Archaeology ${ }^{88}$. The Coptic artist represented the wind moving the sail through the carved lines, and the water under the boat represented by slanted lines I// (Fig. 24.e).

\section{Doc.15: Limestone Fragment of a Stela Representing Three Men}

This limestone fragment was found in Meydum, preserved in the Staatliche Museen no. 9625 , dates to VI century, measuring 40x52 cm. Three figures are shown in a rigid frontal view. They are dressed in simple sleeveless tunics that reach down to their ankles. The figure on the right stands in an anchored ship between the mast and the raised prow, raising one arm in a prayer attitude, and the other hand is behind the mast, The center of the relief is occupied by a bearded man with parted hair and arms raised in prayer, his name 'Klam' probably an abbreviation or a nickname is carved over the head. To his left stands another figure raised on a kind of pedestal with arms

\footnotetext{
${ }^{82} \mathrm{Xc}=90$ may be referring to his age.

${ }^{83}$ Kelsley Museum exhibition KM21188; F.A. Hooper, op.cit, Acc. 21188, pl. XIVd.

${ }^{84}$ https://exhibitions.kelsey.lsa.umich.edu/galleries/Exhibits/PortalsToEternity/21188.html

${ }^{85}$ Kelsley Museum's exhibition KM21190; F.A. Hooper, op.cit, Acc. 21188, pl. XVa.

${ }^{86}$ F.A. Hooper, op.cit, pl. xvc.

${ }^{87}$ Ibid, pl. xvb.

${ }^{88}$ Z. Hawass, Hidden Treasures of the Egyptian Museum, the American University in Cairo Press, Cairo, 2002.
} 
raised in prayer (Fig. 24.f) ${ }^{89}$. N.B., this piece is added among the collection of Kom Abu Billou due to its strong similarity with them that can be observed through their face features.

\section{Doc.16: Stela of "Peter the Monk"}

A limestone stele, from Akhmim or Armant (?), preserved in the Coptic Museum no. 7730 , measuring $30 \times 39 \mathrm{~cm}$., dates to $3^{\text {rd }}$ century. Its lower part is decorated by a boat with a sail in the form of Christogram ${ }^{90}$ "Christ's monogram" composed of chi and rho the first letters in the Christ's name ${ }^{91}$. A line of inscriptions separating the upper and lower part of the stela, reads as following, "пєтрос monwхос" means "Peter the monk" 92 . The upper part takes the shape of a Tympanon with a circle in the middle flanked by foliage, surmounting a cross with a side braid flanked by two ankh crosses $^{93}$ from each side (Fig.25).

The sculptor used a simple way of incision, the style is very close to the ancient Egyptian stelas with the sun god "Re" travelling to the otherworld, but the Christ's monogram here replaces the sun. The Christ's monogram and the boat have a spiritual meaning, which is crossing the world and reaching the shore of eternity ${ }^{94}$. The ancient Egyptian influence is Dominant in this stela, not only in the style of the boat carrying the monogram but also the ankh crosses and the side braid added to the middle cross.

According to D. Benazeth, the symbols in the stela have strong indication, emphasizing the monk's faith and his humility appeared in the stela's simplicity that has only his name and job, and added that the boat here has a Christian symbolism, referring to the church of the believers managed by Peter or the Christ himself, while its mast is replaced by the Christ's monogram ${ }^{95}$.

\footnotetext{
${ }^{89}$ A. Badawy, Coptic Art and Archeology, the Art of the Christian Egyptians from the Late Antique to Middle Ages, Mit Press, Cambridge, Massaclusette, London and England, 1978, p.211, fig. 3.194; https://smb.museum-digital.de/singleimage.php?resourcenr=163640.

* The Christogram is the oldest of all the symbols evoking the Christ. F.A. Hooper, Funerary Stelae from Kom Abou Billou, Kelsey Museum of Archaeology, 1961, p. 1-3; G. Gabra and M.E. Krauss, the Treasures of Coptic Art in the Coptic Museum and Churches of Old Cairo, the American University in Cairo Press, p.49.

${ }^{91}$ M.W. Crum, Catalogue général des antiquités du musée du Caire, Coptic monuments, Le Caire, 1902, no. 8574, pl.XXX; L. Torok, Egypt after the Pharaohs, p. 50, pl. 32; F.A. Hooper, op.cit, p. 1-3; G. Gabra and M.E. Krauss, op.cit, p.49, no.32; 345 دعاء محمد بهي الدين, المرجع السابق, صopt

${ }^{92}$ D. Benazeth, "Les coutumes funérairess", L' art Copte en Égypte 2000 ans de Christianisme:

Exposition présentée à l' Institut du Monde Arabe, Paris, Gallimard, Paris, 2000, p. 129, no. 108;

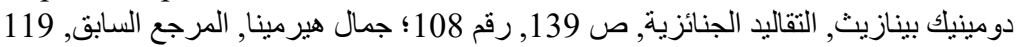

${ }^{93}$ The Anch cross or the looped cross (crux ansata) appeared during the early period as the result of the Christian persecution, to be used as a hidden symbol. This type of cross was confined to the Christians of Egypt, it is totally Coptic عزت زكي حامد قادوس, تاريخ عام الفنون, الإسكندرية, 2011, ص 1989 .

${ }^{94}$ N. Attala, Coptic Art, Vol II, Cairo, 1989, p. 44, 45; M.M. Anwar considered the boat represented in this stela to be a solar boat symbolizing the church from one part and the sun from the other part. M.M. Anwar, " $\mathrm{L}$ ' etude du patrimoine Copte a travers les phenomenes cosmiques dans l'art Copte", BSAC, Tome LVII, Le Caire, 2018, p. 39, fig. 1.

${ }^{95}$ M.H. Rutschuwskaya et D. Benazeth, "Les coutumes funérairess", L' art Copte en Égypte 2000 ans de christianisme, Gallimard, Paris, 2000, p. 129, no. 108.
} 


\section{V-Boats Carved on Stones}

\section{Doc.17: Fishing in Marshes on a Limestone Archivolt}

The importance of the Nile along man's life was reflected on his monuments, the representation of riverine fauna and flora were depicted on the wall paintings of the tombs and temples and on artifacts ${ }^{96}$.

One of the unique pieces representing Nilotic scenes, is a limestone segment of an archivolt dates to $5^{\text {th }} / 6^{\text {th }}$ century, measures $33 \times 48 \mathrm{~cm}$, probably from Coptos ${ }^{97}$, now preserved in the Coptic Museum no. 8002, Hall.8, purchased by G. Maspero 1911 (Fig. 26) ${ }^{98}$.

A fine relief curved using a flat technique. The scene representing a fisherman in a crescent shaped skiff pulling a big fish by the robe of his fishing rod. The artist here filled the bottom with aquatic flowers, lotus, and papyrus. Two ducks sitting among these flowers and their nest filled with five eggs behind them. The details of the relief, especially that of the bird's nest holding eggs and the fisherman, are vividly portrayed. A border of heart-shaped foliage with interspersed beads framing the scene is Greek in origin ${ }^{99}$. The form of the lotus flowers and the boat gives the indication that the fishing is in the Nile ${ }^{100}$.

The ancient Egyptian influence in this piece is very clear. The scene imitates the ancient Egyptian scenes of hunting in swamps which is considered among the most loveable scenes especially on the interior walls of the ancient Egyptian tombs of nobles during the $5^{\text {th }}-18^{\text {th }}$ dynasty ${ }^{101}$.

\section{Doc.18: A Limestone Fragment with Nilotic Scene}

A limestone piece found in Saqqara, was a part of one of the monastery church's façade, dates to $4^{\text {th }}-5^{\text {th }}$ century, showing fishing in the countryside's swamps (Fig.27) ${ }^{102}$, the man is standing in the skiff holding his hook and hunting a big tilapia fish. The scene is filled with details, a big crocodile is at the top of the scene, and the fisherman is surrounded by fishes and plants. One can observe that the artist is filling the spaces in the scene with more details, applying one of the characteristics of the Coptic art known as the horror vacui (the fear of emptiness).

\footnotetext{
${ }^{96}$ F.A. Hooper, op.cit, p. 1-3; G. Gabra and M.E. Krauss, op.cit, p. 35.

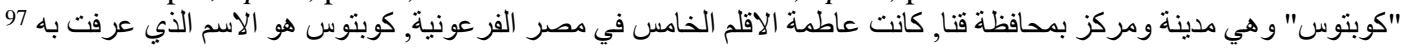

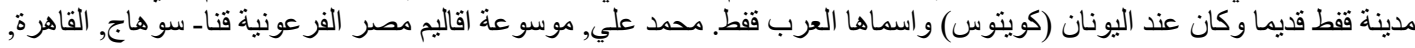

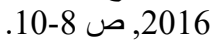

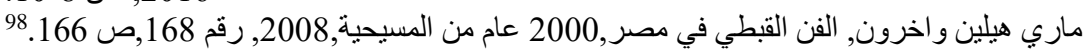

${ }^{99}$ N. Selim, Coptic Art, vol II, p. 66, 67, Nr. 8002 ؛ M. de Villard, La Sculptura ad Ahnas, Milano, fig.

57; M.H.Rutschuwskaya et D. Benazeth, op.cit, p. 166, no. 169; F.A. Hooper, Funerary Stelae from

Jوف حبيب, الاثر المصري القديم ; Kom Abou Billou, op.cit, p. 1-3; G. Gabra and M.E. Krauss, op.cit, p. 35

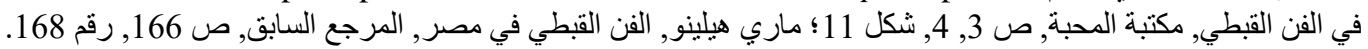

${ }^{100}$ G. Duthuit, La sculpture Copte, Paris, 1931, pl. XXXIIC.

${ }^{101}$ G. Gabra, Cairo the Coptic Museum, 1993, no.17, p.69; A. Badawy, l'art Copte, les influences

Egyptiennes, Preface par E. Driton, Le Caire, 1949, fig. 53; Sh. El Gendi, "Woodwork from the Coptic Museum displayed in the Antiquities Museum of the Library of Alexandria", $B S A C$, tome 58, le caire, 2019, p. 45, fig.3.

${ }^{102}$ R. Habib, Everyday Life from Coptic Antiquities, Mahaba Bookshop, p.5, fig.11.
} 


\section{VI-Boats on Bones}

\section{Doc.19: Bone Carving in Brooklyn Museum:}

A piece of bone representing a Nilotic scene, dates to $3^{\text {rd }}-5^{\text {th }}$ century A.D, measuring $0.52 \times 112 \mathrm{~m}$, unknown provenance with Alexandrian type (Fig.28) ${ }^{103}$. It's suggested that it shows a naked man stands in a small skiff holding a hook and about to get a fish, while behind him is another naked man fishing by his hand, indicating that the water is superficial.

\section{VII-Boats on Wood}

\section{Doc.20: A Piece of Wood Representing Pottery Transportation by Boat}

A scene that is rarely appeared in Coptic art on a piece of wood, dates to the Fourth Century, exhibited in the Coptic Museum no. 4876, representing transporting amphoras jars filled with liquids and closed by stoppers, arranged on a Nile boat by the same way used by the ancient Egyptians. The artist here represented the water by the presence of a crocodile at the bottom, which is about to attack the boatman who is leaning over the boat's prow (Fig.29). Its usual to find the processes of transportation by land through the Coptic art, but it is rare to find the scenes of transportation by boats ${ }^{104}$.

\section{VIII- Boats on Terracotta}

Doc.21: A unique terracotta pilgrim flask, its decoration is sailing boat, found in the region of Abu Mena, dates to Sixth-Seventh century (Fig.30) ${ }^{105}$. The boat represented on the flask takes the shape of a small, curved skiff with long mast and sail, it's suggested to be used in the pilgrimage to reach the region of Abu Mena.

VIV-Boats on Textile: The Boats representation on textiles appeared through the daily life scenes and as a part of the mythological scenes.

\section{VIV. a: Boats Among the Daily Life Scenes on a Linen Tunic}

Doc.22: On a portion of a linen tunic among the collection of Victoria and Albert Museum no. 626. Its lower border has three large circles; the second circle contains two men standing on a lake and a man in a boat, the scene is repeated twice. The circles are outlined by a row of heart shaped floral forms, edged by geometrical and interlaced ornament. The tunic came from Egypt, but the site is unrecorded, among the collection of Robert Taylor, dates to $6^{\text {th }}-7^{\text {th }}$ century, but the shoulder band appears to be later than the tapestry work itself may be $8^{\text {th }}$ or $9^{\text {th }}$ century (Fig.31) $)^{106}$.

\footnotetext{
${ }^{103}$ Pagan and Christian Egypt Egyptian art from the First to the Tenth century A.D, exhibited at the Brooklyn Museum by the department of ancient art jan23-March 9/1941, Brooklyn institute of arts and sciences, 1974, no.95.

${ }^{104}$ R. Habib, Everyday Life from Coptic Antiquities, op.cit, p.4, fig.6; L. Torok, Transfigurations of

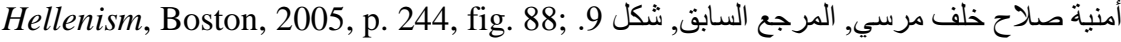

105 O.M Dalton, Catalogue of Early Christian Antiquities and Objects from Christian East, London, 1901, p. 156; G. Vikan, Byzantine Pilgrimage Art, Dumbarton Oaks Trustees for Harvard University Washington, 1982, Fig.11.

${ }^{106}$ A.F. Kendrick, op.cit, 1922, p. 10, 11, pl. VI, no. 626.
} 


\section{VIV. b: Boats as a Part of Mythological Scenes on Textiles}

One of the repeated topics especially on textiles are the Nereids, swimming with the winged nymphs and fishes ${ }^{107}$. The Nereids were the daughters of Neros the god of the sea in Greek mythology, they were maidens associated with water, they served a lively motif in Coptic art. The different exchanges between Rome and Alexandria and the common element of water in the Nile River and the seas helped the spread of the theme in Egypt, which originally appeared in mosaic floors in the Hellenistic and Roman periods. Later, they were used in Coptic art on stones and widely in decorative tapestries, hangings, and tunics. They may be part of the sea cycles involving Poseidon (lord of the sea), or Aphrodite, or of the river cycles centering on the Nile or the Tiber rivers. In the Nile cycles they were often confused with putti, sometimes they appear alone or may offer a cup, with a religious implication ${ }^{108}$.

The Nereids had survived as a pagan motive to the last manifestations of Coptic art in the twelfth century. They even were sometimes accompanied with a cross or a nimbus supporting a cross. Its Christian meaning still implicit as the processions of Nereids and Putti may be linked with Aphrodite, symbolizing rebirth of the soul in the waters of Baptism ${ }^{109}$. The Pagan Nilotic scenes were frequently used by the Coptic weavers especially during the $5^{\text {th }}$ century. The Copts were no less aware of the importance of the river and its god as the Ptolemaic and Romans ${ }^{110}$.

Doc.23: A decorative square panel of textile dates to the $5^{\text {th }}$ century, preserved in Louvre Museum, decorated with fishermen, children, nereids, ducks, fishes, and lotus flowers ${ }^{111}$. The panel's border is decorated with nereids sitting in small black boats or standing and holding a cup in their hands. (Fig.32) ${ }^{112}$.

Doc.24: A piece of tapestry, showing nereids on a sea monster ${ }^{113}$, in the left side lower corner is a beautiful representation of two nude children in a boat and gathering lotus in happiness (Fig.33). This scene is repeated on several pieces of textiles preserved in different Museums, as it was one of the familiar scenes appeared on textiles. This piece measures $30 \times 30 \mathrm{~cm}$, dates to $6^{\text {th }}$ century ${ }^{114}$.

\footnotetext{
عادل فخري صادق, "النيل ومكانته في الحقبة القبطية", راكوتي, السنة الأولي العدد الثالث سبتمبر 2004, القاهرة, 21, 22. ${ }^{108}$ P. Du bourguet., "Nereids, Mythological Subjects in Coptic Art", CE, vol. 6, 1750a-1768b; P. Du bourguet, "Nilotic scenes, Mythological Subjects in Coptic Art", CE, Vol. 6, 1750a-1768b; P. Du porguet L'art Copt, Paris, 1968, p. 52.

${ }^{109}$ P. Du bourguet., "Nereids", op.cit, $C E$ 1750a-1768b; P. du bourguet, "Nilotic scenes", op.cit, $C E$ 1750a-1768b.

${ }^{110}$ P. Du bourguet, "Nilotic Scenes", CE 1750a-1768b.

${ }^{111}$ W.F. Volbach, Early Decorative Textiles, Paul Hamlyn, 1969, p. 12, no.2; P. du Bourguet, Musée national du Louvre catalogues des etoffes Coptes I, c.76; Pagan and Christian Egypt, op.cit, no. 222; P. du Bourguet, etoffes coptes I, C. 78, D.36, 37.

${ }^{112}$ P. Du porguet, the Art of the Copts, Paris, 1968, p. 52.

${ }^{113}$ Pagan and Christian Egypt, op.cit, no. 222. Also, the same scene repeated on another piece of tapestry preserved in the same museum no. 217.

${ }^{114}$ P. du Bourguet, etoffes Coptes I, C. 78, D.36, 37.
} 


\section{Analysis}

This part is based on analyzing different scenes representing watercrafts, based on what explained in detail through this research.

Egypt was crisscrossed by the Nile, canals, and seas, that connected the country together. Ships, boats and different watercraft were the main means of transporting people and goods, they used it by its various sizes and types: the Skiff that might be capable of carrying only a single person was the simplest type of boats used in ancient Egypt, made of papyrus reeds tied together by ropes, and it was the dominant type used for travelling short distances and fishing in marshes, beside these small skiffs they started to make Wooden boats with oars, cabins, masts, sails and sometimes rudders. These small boats quickly developed into huge Cargo ships suitable to carry heavy stones and blocks.

\section{Analysis According to the Boat's Structure Represented in the Documents}

- Oars: it did not exceed two in all figures represented, while in ancient Egypt reached forty oars per one boat.

- Anchors: appeared only once in the big ship of Baouit (Fig.22.b).

- Cabins: appeared through Noah's Ark in the chapel of Exodus (Fig.15), the latterly added boat in the same chapel (Fig.17), and the ship represented in Baouit (Fig.22.b).

- Rudders: despite its representation in the ancient Egyptian art, but it did not appear in any of the discussed examples related to the Coptic art.

- Masts and Sails: repeated in several examples especially in wall paintings and stelae, only one unique example appeared in the stela of Peter (Fig.25) in replacing the mast with the Christ's monogram, adding Christian symbolism.

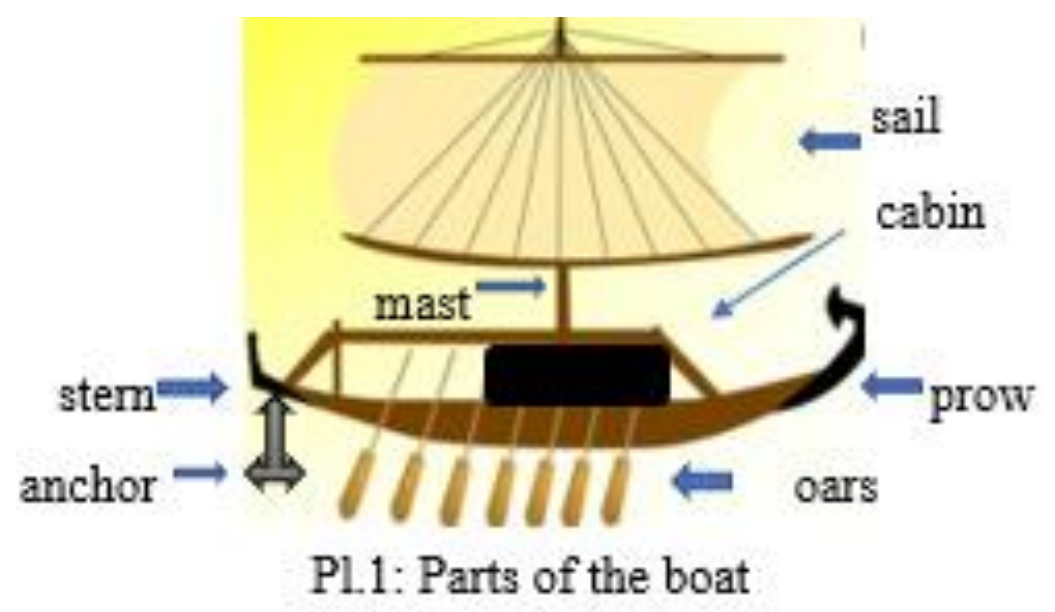




\section{Table 1}

Different Types of Watercrafts represented Through the Study:

Small skiff: usually connected with fishing in marshes, suitable to carry one person or few number.

Boats with sails: represented on the walls of El Bagawat, Apa Apollo and Apa Jeremiah monasteries, and on terracotta. It helped in transportation and fishing by nets.

Funerary boats: Symbolic boats, appeared only during the early Byzantine Period and disappeared by time.

Big ships: big ships used for transportation or transporting goods for long distances. Only one example found in the monastery of Baouit (Fig.22.b).
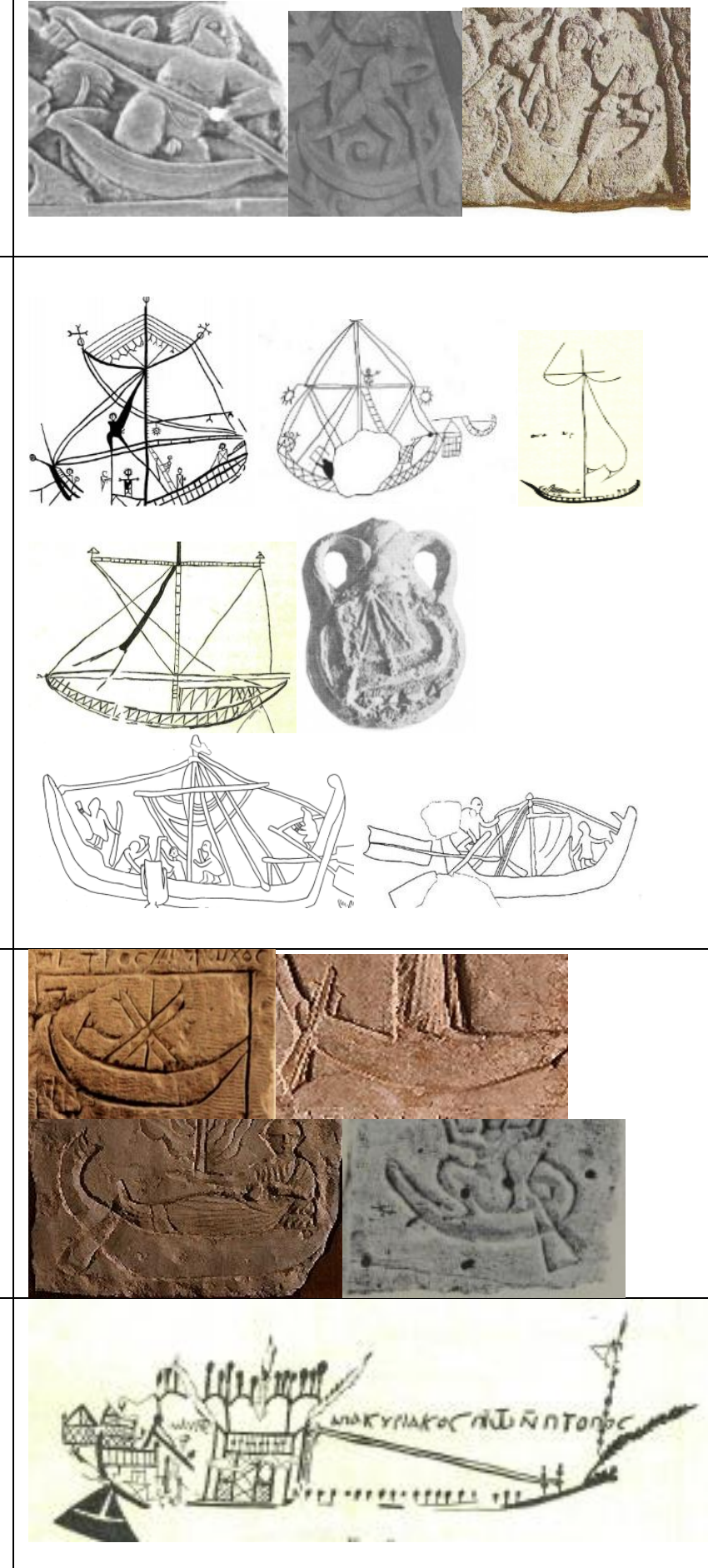

Continued 


Boats in Religious Stories:
-Noah's Ark despite it was
described as a huge Ark in the
original story, but the Coptic artist
represented it as a normal boat in
size.
-Distinguished by being totally
covered from the top as described
in the real story.
-Jonah's boat represented simply
with not too many details.
Boats in Mythological scenes:
Small tiny boats carrying Nereids
and small naked children,
represented within the
mythological context.

\section{-The Ancient Egyptian Influence in the Scenes}

- The Coptic artist is the grandson of the ancient Egyptians, so it was normal to find the Egyptian effect in the Coptic art through representing the Nilotic and daily life scene e.g., Figs no. $(26,27,28)$. In Fig.26 the whole scene was very familiar in ancient Egypt, the similarity appeared through the skiff's shape, ducks, tilapia fishes, the birds' nest filled with eggs and the lotus plants.

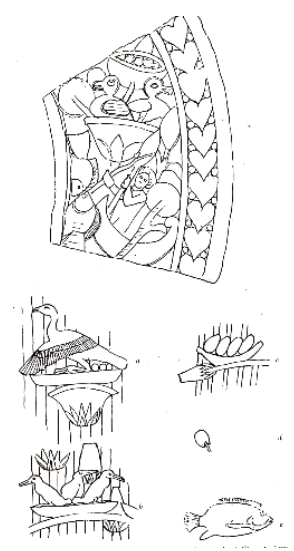

Pl.2. A Coptic Nilotic scene and the ancient Egyptian effect from the tomb of Ti, the tomb of Ankh and the tomb of Aba.

After: A. Badawy, L'art Copte, les influences Egyptiennes, fig. 53. 
- The looped cross and the cross with side braid appeared on the stela of "Peter the monk" (Fig.25), were purely of Egyptian origin.

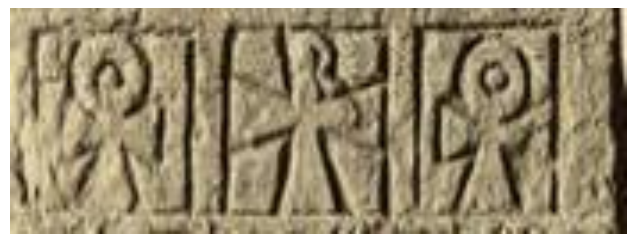

Pl.3. Part of the stela of Peter.

- The Copts as their ancestors used to leave graffiti on the walls of their visited places, this can be seen on the walls of El Bagawat and the monastery of Apa Jeremiah and Apa Apollo, when tracing this type of graffiti, it is found that there is a great similarity to that related to the Middle Kingdom found in the boat pit at Abydos.
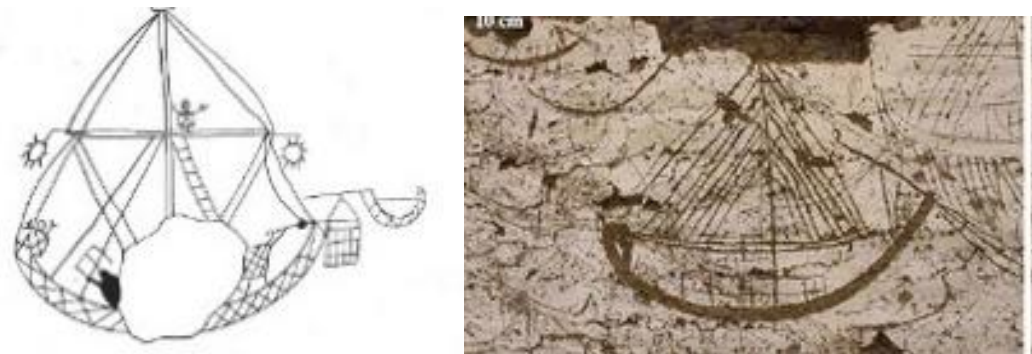

Pl.4. Graffiti from chapel no.20 at El Bagawaat; graffiti from the boat pit at Abydos.

- The scene of transporting the amphoras by boat, was one of the repeated scenes in ancient Egypt, but it is rarely represented in Coptic art. One can observe the way of arranging the vessels on the boat and the stoppers used in the wooden fragment, is very close to that appeared in ancient Egypt. E.g., the painting on the west wall of the pillared court in the tomb of Feteky at Abusir, Old Kingdom, $5^{\text {th }}$ dynasty.
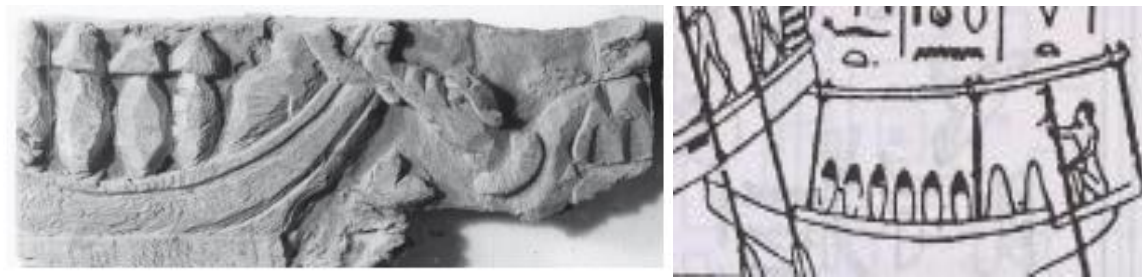

Pl.5. Transporting amphoras by boat on a wooden fragment dates to $4^{\text {th }}$ century; a scene from the west wall of the pillared court in the tomb of Feteky at Abusir. After: L. Torok, Transfigurations of Hellenism, fig.88; H. Altenmüller, "Funerary Boats and Boat Pits of the Old Kingdom”, P. 276, fig.4.

- The deceased in a boat alone or accompanying people in farewelling him, a scene only represented on the early Coptic stelea and did not repeat in any later artifacts (disappeared after a time), indicating that it is of ancient Egyptian origin and not Coptic. 


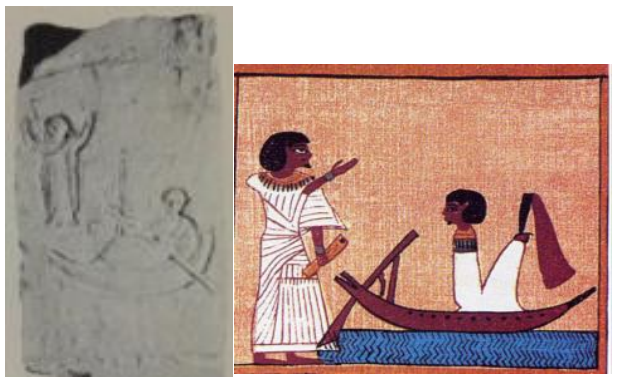

Pl.6. A stela from Kom Abu Billou representing the deceased in a boat; Transporting the deceased across the waterway in the mhnt boat from the funerary papyrus of Ani XIX Dynasty.

\section{Conclusion}

- This research is dealt with studying different watercrafts specially boats during the Byzantine Period and tracing its roots from ancient Egypt. The first part is arranged according to the date of the scene, while starting from the Byzantine period it arranged according to the material, due to the inaccuracy of dating the Coptic pieces.

\section{From the study it was concluded that}

- dpt as their common name in ancient Egypt, were in everywhere and significantly important to many aspects of life such as economic, military, political, religious, ceremonial, funeral, transportation, and daily life. Their interest in boats reached its burial, many boat graves for royal and non-royal boats were found.

- As the ancient Egyptian man used to record all his life aspects, boats had a big opportunity in appearance since the Pred-dynastic period, the theme that continued during the Dynastic periods of the Egyptian civilization, due to its religious and daily importance, as the deceased in ancient Egypt hoped the transition to the otherworld through the Nile, this was beside its importance in the normal daily life uses. The Greeks and Romans adopted the importance of the boats, showing it clearly through their arts. During the Byzantine period its importance did not decrease in normal uses but in art one can observe the disappearance of few types that were used in ancient Egypt, and it gained different meaning in symbolism according to the new Christian religion.

- The ancient Egyptian influence that is touchable in the scenes during the early Byzantine Period especially in Kom Abu Billou's stelea was normal, as the Coptic artist was influenced by his ancient Egyptian ancestors and that reflected through his art which is gradually changed to serve his religion. The boat was one of their secret symbols used in reference to the church, best indication for its symbolism, is the wall painting found in the monastery of St. Jeremiah (Fig.20), the boat is topped with three crosses, resembling a church with three domes topped with crosses, and the stela of Peter in adding the Christ's monogram, instead of the mast (Fig.25).

- There was an observation on the murals with scenes representing boats especially those represented in El Bagawat and the monasteries, is that these areas are away 
from the aquatic environment, in spite of that fishing with nets were represented. After examining these examples, it is concluded that the main objective from its representation was its symbolic representation in referring to the religious meaning.

Boats representation in art were very important and helped in tracing its roots from the Predynastic till the Byzantine Period

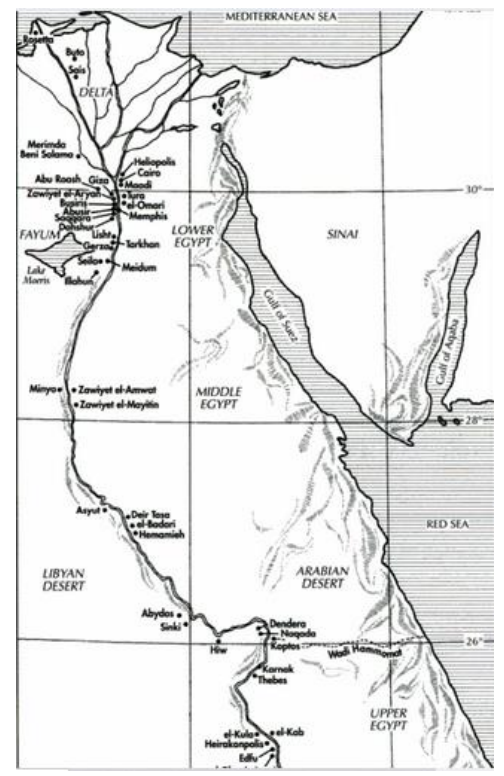

Fig.1. Map of the cultural centers along the Nile River.

After: M. Isler, Sticks, Stones and Shadows, Building the Egyptian Pyramids, University of Oklahoma Press, 2001, Fig 2.1.
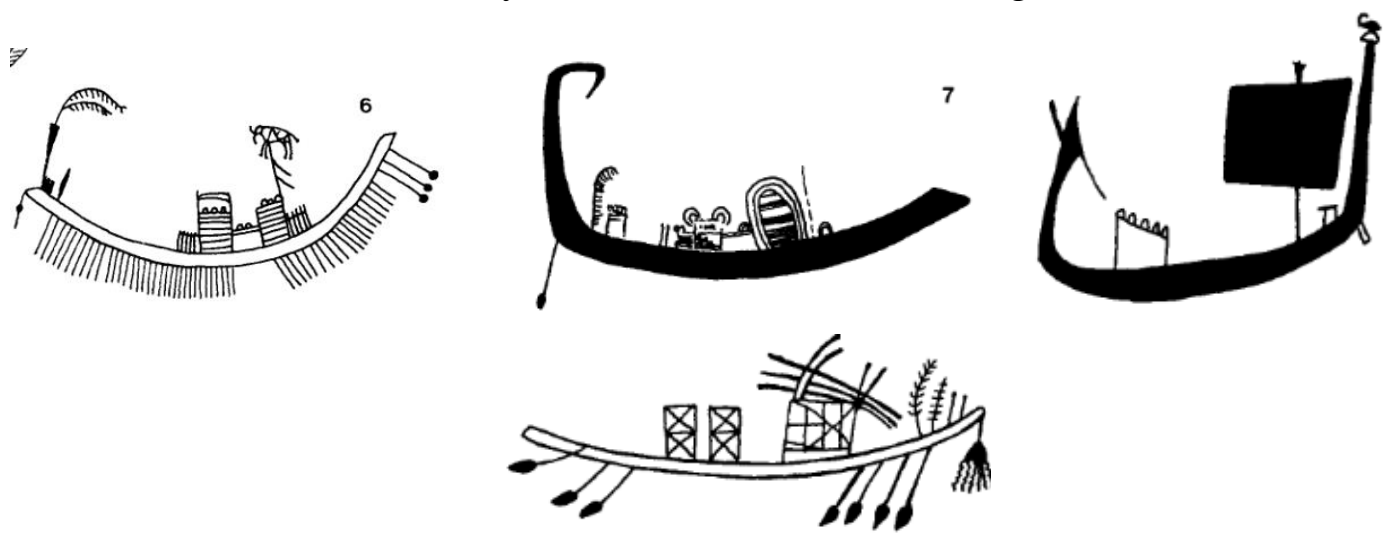

Fig.2. Different examples for the Gerzean boats.

After: F. El-Yahky, "Clarifications on the Gerzean Boat Scenes", BIFAO 85(1985), p. 187- 195, pl. xxxiii, xxxiv. 


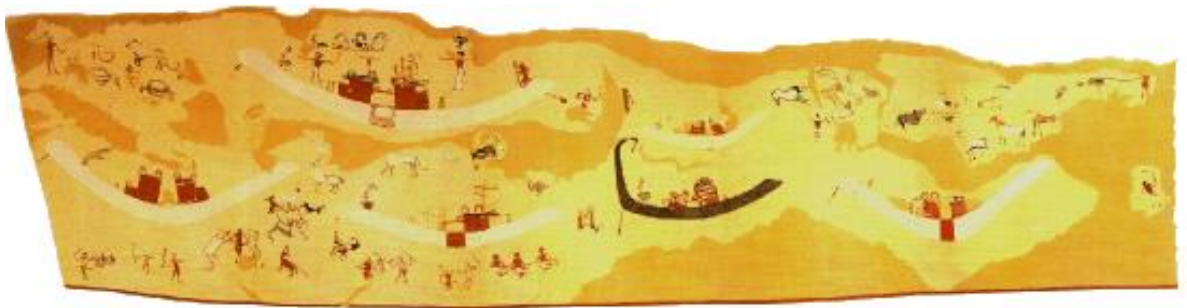

Fig.3. Plan and section of the painted tomb no.100 at Hierakonpolis. After: J.E. Quibelle and F.W. Green, Hierakonpolis, Part II, London, 1902, PL. LXVII.

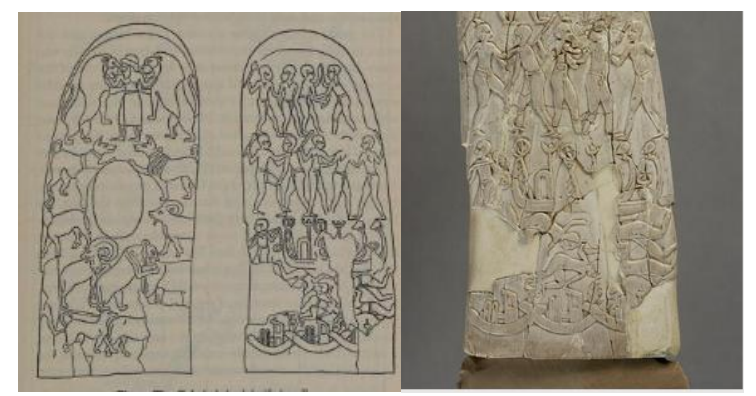

Fig.4. Ships on an ivory knife handle, from Nakada II, now preserved in Louvre Museum E11517, bought by G.A. Benedite in 1914.

After: W.B. Emery, Archaic Egypt, London, 1961, fig. 1;

https://collections.louvre.fr/ark:/53355/c1010007467

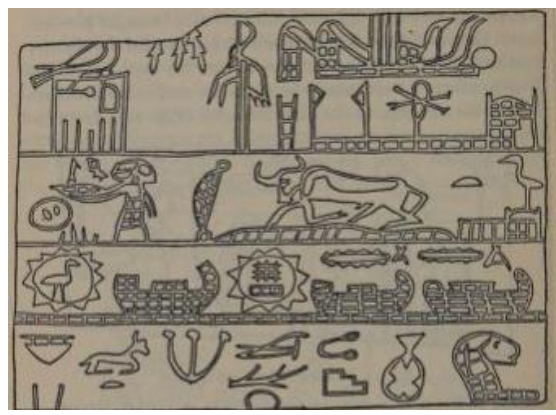

Fig.5. Boats on wooden label from Abydos

After: W.B. Emery, Archaic Egypt, fig. 12.

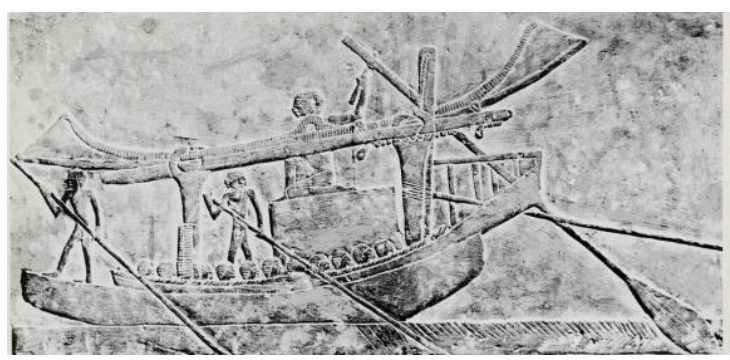

Fig.6. Limestone relied in the tomb of Ipi, representing a cargo boat carrying a huge block of stones, Saqqara, $6^{\text {th }}$ Dynasty, Cairo, Egyptian Museum.

After: E. Strouhal, Life of the Ancient Egyptians, University of Oklahoma Press, London, 1992, P. 178, no. 193. 


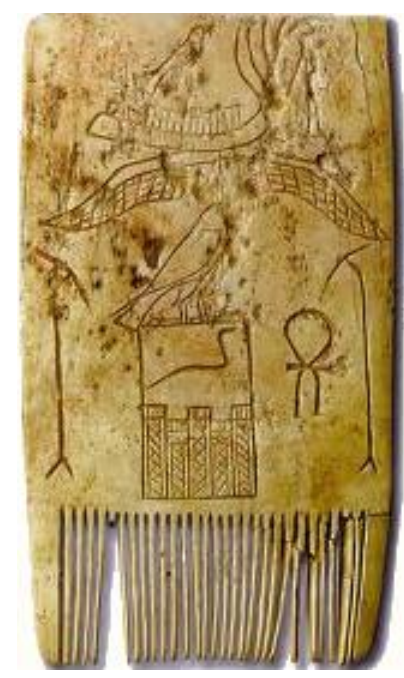

Fig.7. The bark of the God Seker on King Djet's comb, Cairo Museum (JE47176). After: G.J. Tassie, "Hair in Egypt", p. 1057, fig.7c.

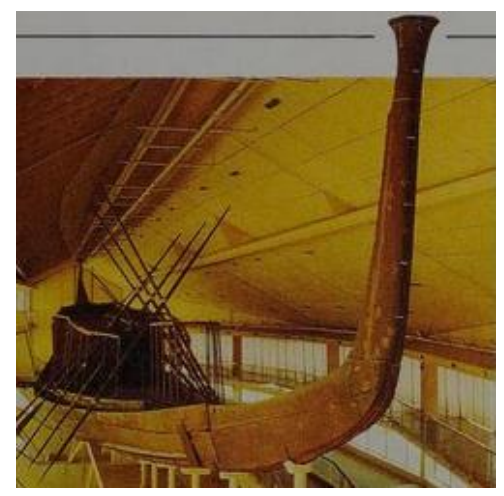

Fig.8. King Khufu's boat on display in Khufu's Solar Boat Museum After: P. James, Pyramid, New York, 1994, p. 29.

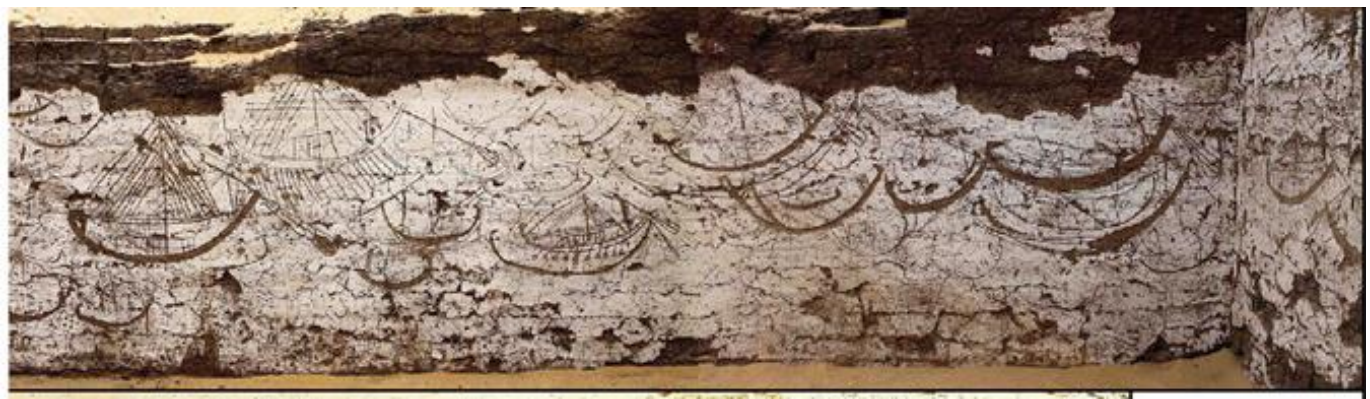

Fig.9. The "Boat Tableau" from Abydos.

After: J. Wegner, “A Royal Boat Burial and Watercraft Tableau of Egypt's $12^{\text {th }}$ Dynasty”, fig. 11. 


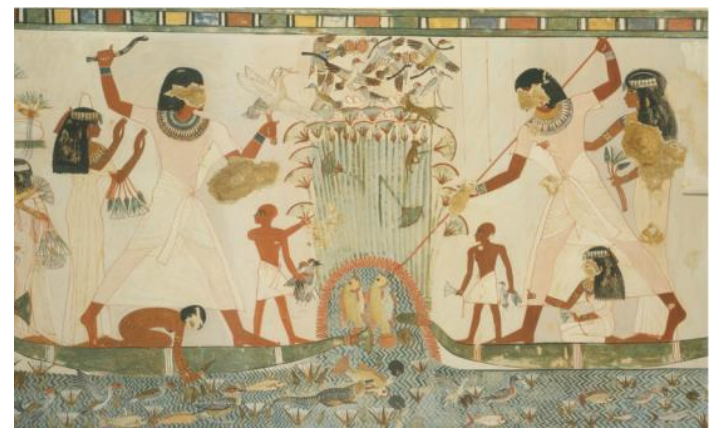

Fig.10. Fishing scenes from the tomb of Menna

After: A. Siliotti, Guide to the Valley of the Kings, New York, 1997, p.155.

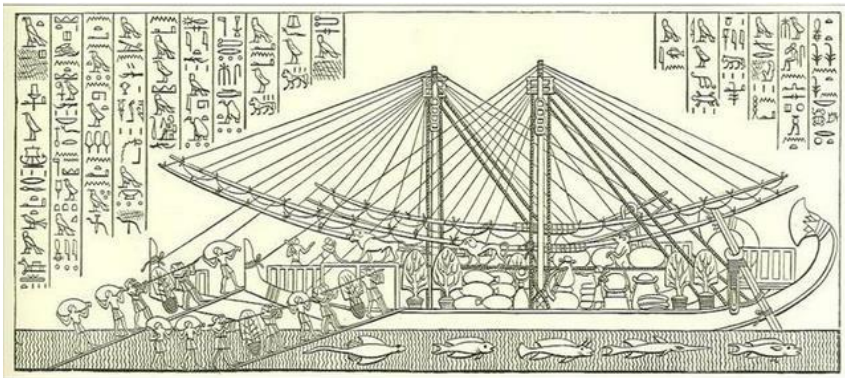

Fig.11. The trip of Hatshepsut to punt from her mortuary temple at Deir El Bahary After: F. Monderson, Hatshepsuts Temple at Deir El Bahari, Bloomington, 2007, P.33.

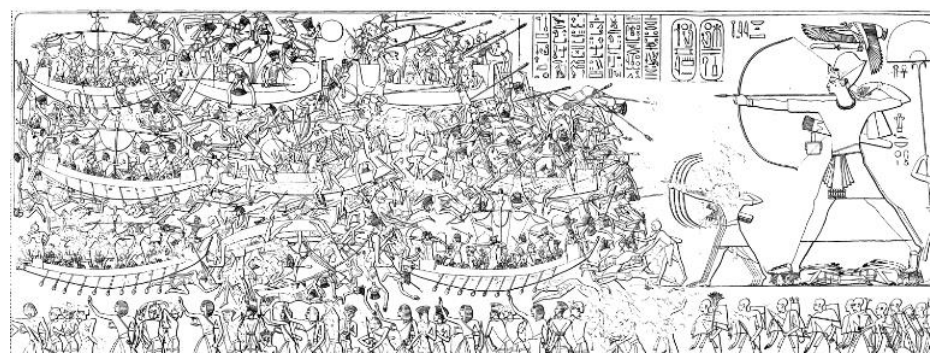

Fig.12. The Naval battle of Ramses III against the sea people, recorded in Medinet Habu. After: H. Nelson, Madinet Habu, Earlier Historical Records of Ramses III, vol. I, the university of Chicago press, Chicago, 1930, pl.37.

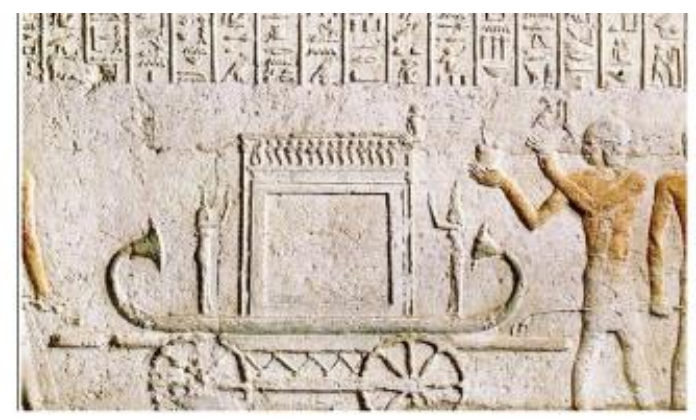

Fig.13. P3-di Petosiris, tuna El Gebel, showing the mummy Neshu's transportation, late dynastic period.

After: W. Omran, "Transporting the deceased by the wheeled cart in the GrecoRoman Tombs", JAAUTH, Vol.17, No2, (2019), pl.1. 


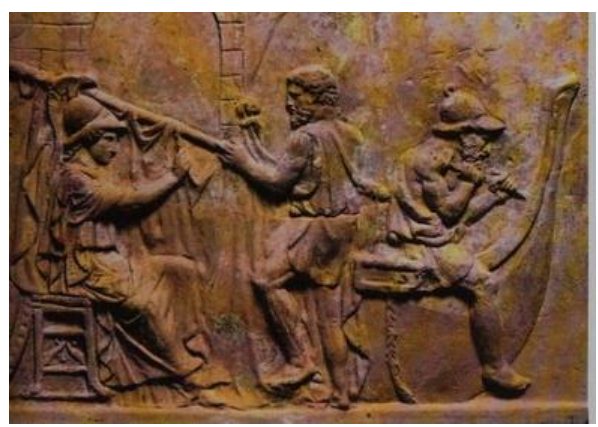

Fig.14. the Argonaut campaign on a clay relief Roman plaque, the Goddess Athena supervising the construction of the Argo and helping the craftsman in setting its mast.

$1^{\text {st }}$ half of the First century A.D., London, British Museum.

After: S. Souli, Greek Mythology, Athens, 1995, p. 97.

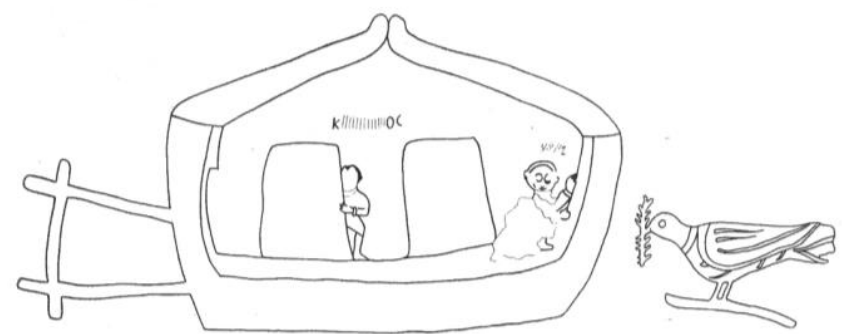

Fig.15. the story of Noah and his Ark from the chapel of Exodus no.30 in Kharga oasis, $3^{\text {rd }} / 4^{\text {th }}$ Century.

After: A. Fakhry, the Necropolis of el-Bagawat in Kharga Oasis, 1951, p. 56, fig.39.

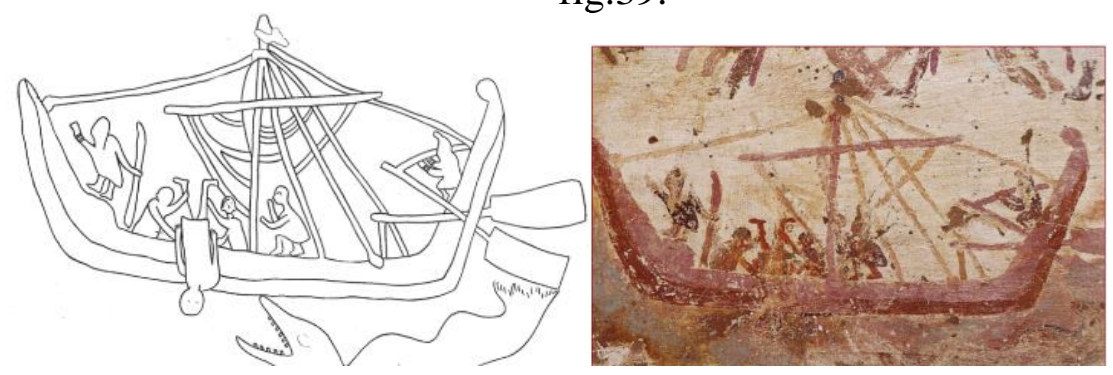

Fig.16. The story of Jonah the chapel of Exodus no. 30 in Kharga oasis, $3^{\text {rd }} / 4^{\text {th }}$ century. After: A. Fakhry, the Necropolis of el-Bagawat in Kharga Oasis, p. 59, fig.44.
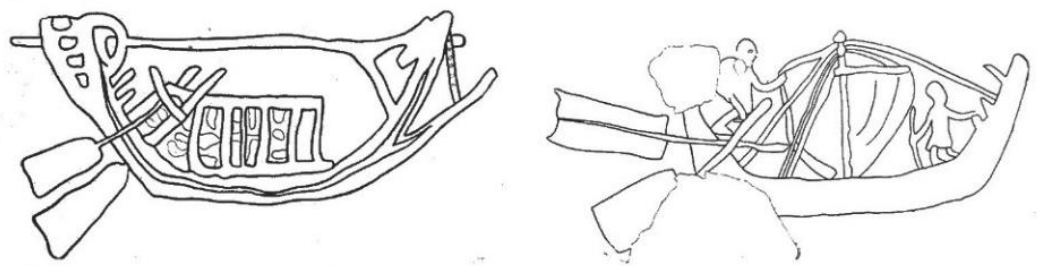

Fig.17a,b: Later addition for a primitive form of boats in the chapel of Exodus. After: A. Fakhry, Bagawt, p. 66, fig. 59, 60. 

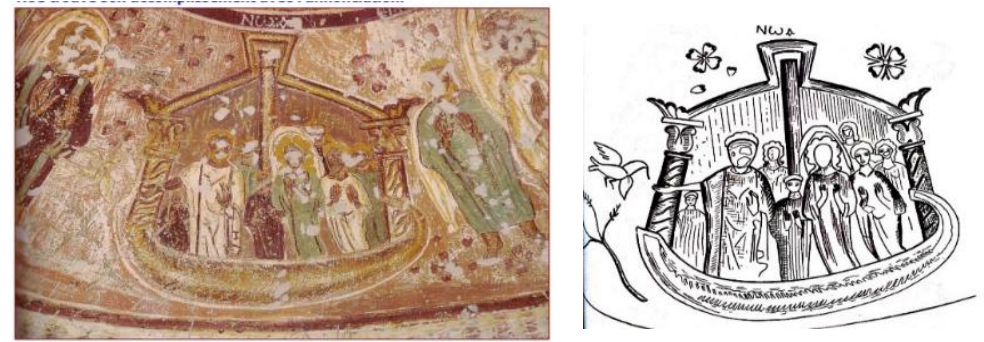

Fig.18. The story of Noah from the Chapel of Peace no. $80,4^{\text {th }} / 5^{\text {th }}$ century. After: A. Fakhry, El Bagawat, p.77, fig. 69.
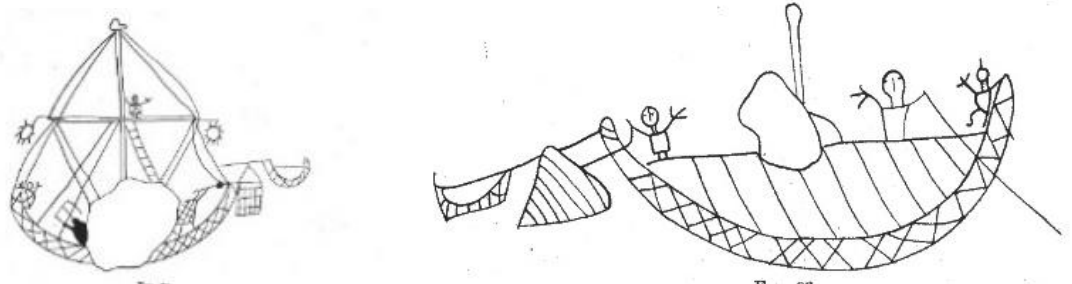

Fig.19. Roughly drawn boat from chapel no. 20 in the necropolis of El Bagawat, $5^{\text {th }}$ century.

After: A. Fakhry, Bagawat, p.118, fig. 93, 94.

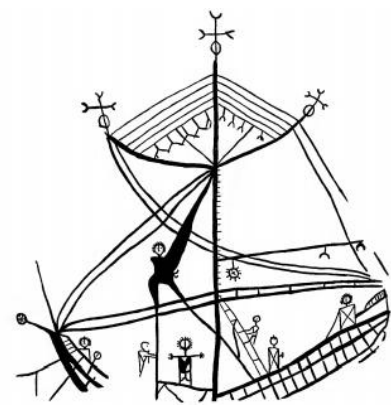

Fig.20. Wall painting for a boat from the monastery of Apa Jeremiah.

After: J.E. Quibell, Excavation at Saqqara (1907-1908), le Caire, 1909, p. 13, no. 782, fig.3.
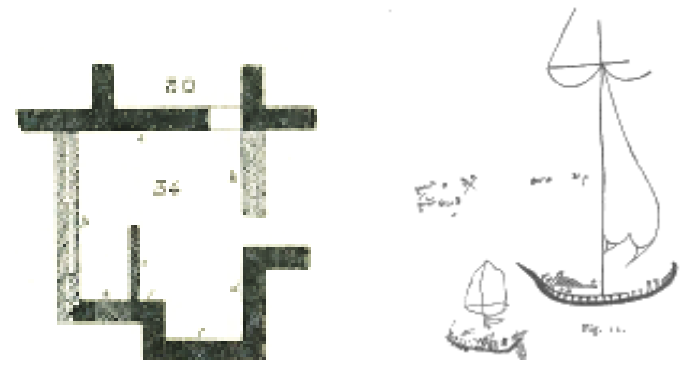

Fig.21 a, b. Plan of Chapel XXXIV in the monastery and the necropolis of Baouit; Wall drawing left on a plastered wall of the Chapel.

After: M.J. Cledat, "Le Monastère et la Nécropole de Baouit", MIFAO, 1916, fig. 10, 11. 


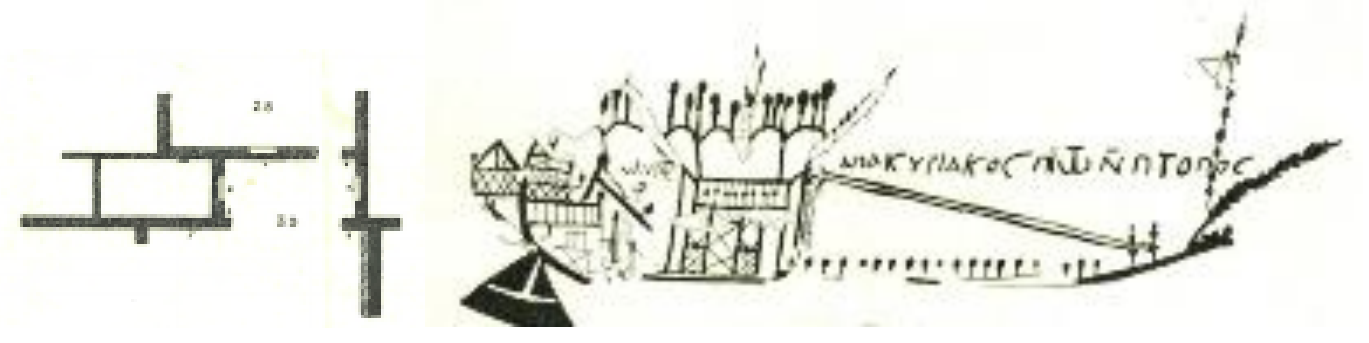

Fig.22a, b. Plan of the Chapel XXXIX in the region of the monastery and necropolis of Baouit; A large ship on the wall of chapel XXXIX.

After: M.J. Cledat, "Le Monastère et la Nécropole de Baouit", MIFAO, 1916,fig.27, 28.

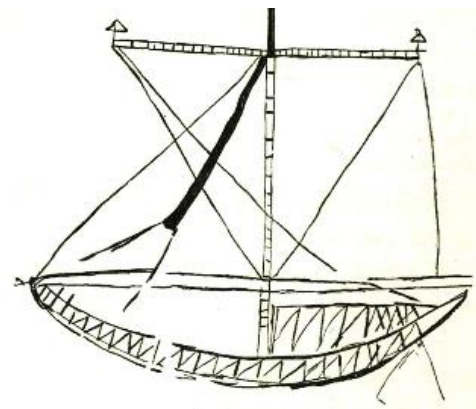

Fig.23. Boat drawing to the left side of the entrance of chapel no. XXVI in the monastery and necropolis of Baouit

After: M.J. Cledat,"Le Monastère et la Nécropole de Baouit", MIFAO , 2eme tome, Le Caire, 1904, p. 133, 139, fig. 62.

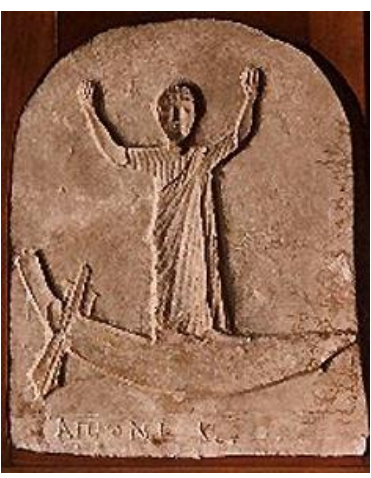

Fig.24. a. Limestone stela for a standing man in a boat, Kom Abou Billou, $2^{\text {nd }}$ century A.D.

After: F. A. Hooper, Funerary Stelae from Kom Abou Billou, Acc. 21188, pl.XIVd;

https://exhibitions.kelsey.lsa.umich.edu/g alleries/Exhibits/PortalsToEternity/21188 .html

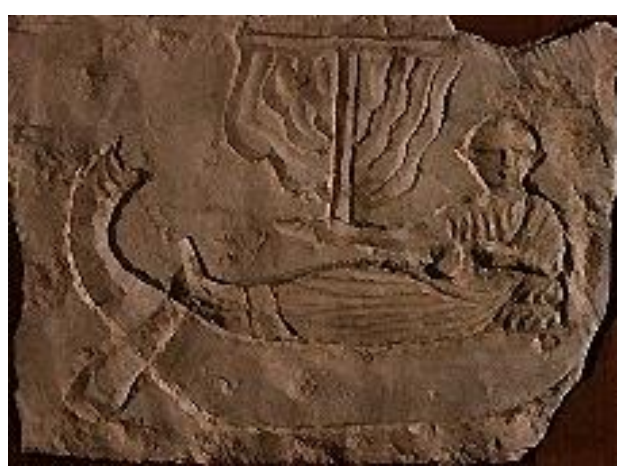

Fig.24. b. Funerary stela for a reclining man in a boat, Kom Abou Billou, mid- $3^{\text {rd }}$ century.

After: F. A. Hooper, op.cit, Acc. 21190, pl. XVa.

https://exhibitions.kelsey.lsa.umich.edu/g alleries/Exhibits/PortalsToEternity/21188 .html; 


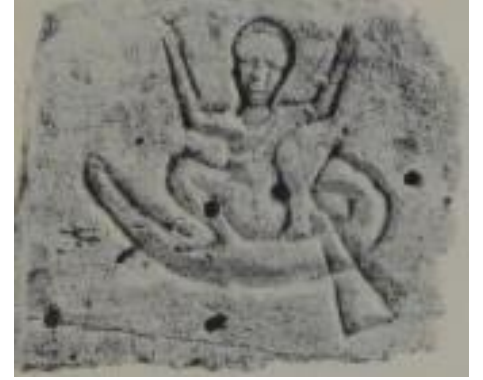

Fig.24. c. A limestone stela for a squatting male in small boat, Kom Abou Billou.

After: F.A. Hooper, op.cit, pl. xvc.

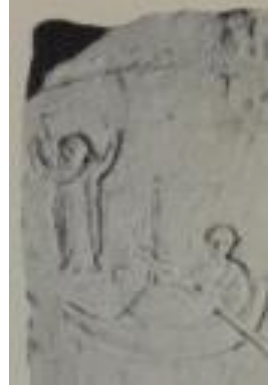

Fig.24. d. A sandy limestone stela for a reclining man in a boat, Kom Abou Billou.

After: F. A.Hooper, op.cit, pl. xvb.

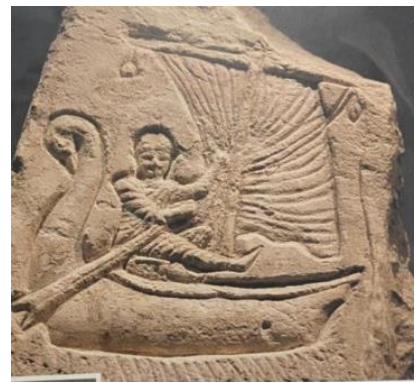

Fig.24. e. Funerary stela, representing a man sailing in a boat, from Kom Abu Billou, $2^{\text {nd }}-3^{\text {rd }}$ Century A.D.

After: Z. Hawass, Hidden Treasures of the Egyptian Museum, the American

University in Cairo Press, Cairo, 2002, p. 22.

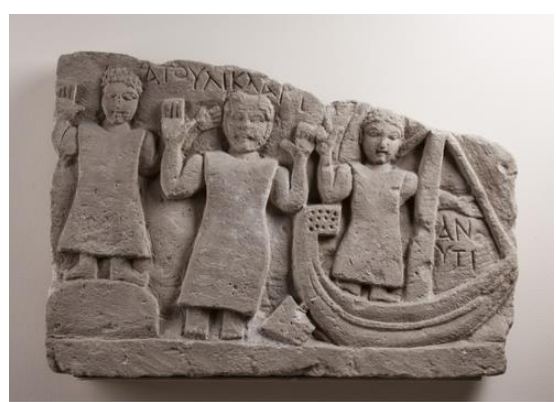

Fig.24. f. Fragment with three figures from Meydum (?), $6^{\text {th }}$ century, Staatliche Museen 9625.

After: A. Badawy, Coptic Art and Archeology, fig. 3.194; https://smb.museumdigital.de/singleimage.php?resourcenr $=163640$. 


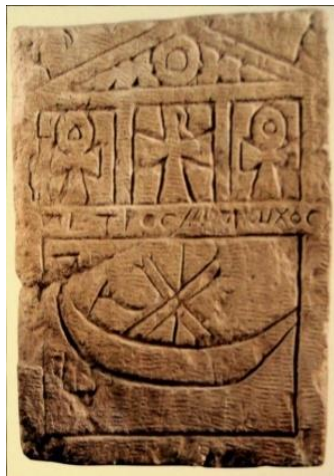

Fig.25. Limestone stele with a boat carrying the Christ's monogram, $3^{\text {rd }}$ century. After: M.W. Crum, Catalogue général des antiquités du musée du Caire, Coptic monuments, Le Caire, 1902., no. 8574, pl.XXX.

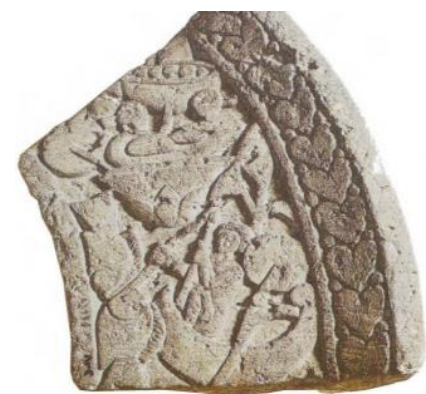

Fig.26. A lower end of a limestone archivolt with fishing scene, Coptos (?), $5^{\text {th }} / 6^{\text {th }}$ Century. After: G. Gabra, Cairo Coptic Museum, Cairo, 1993, no.17, p.69.

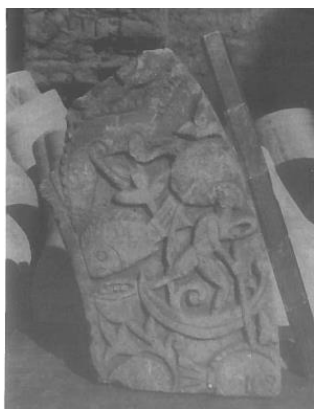

Fig.27. A fragment of a limestone frieze, depicting a man in a boat, from Saqqara, $4^{\text {th }} / 5^{\text {th }}$ Century.

After: R. Habib, Everyday Life from Coptic Antiquities, fig.11.

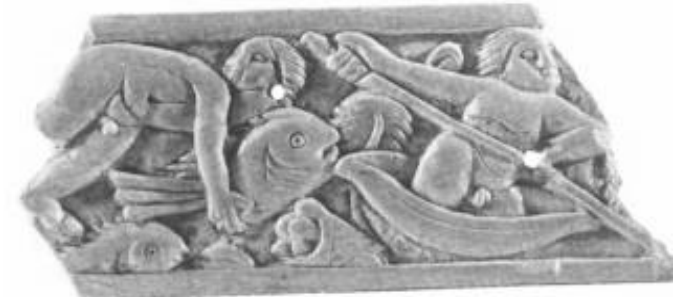

Fig.28. Apiece of bone representing a Nilotic scene, unknown provenance, $3^{\text {rd }} / 5^{\text {th }}$ century. After: Pagan and Christian Egypt Egyptian Art from the First to the Tenth Century A.D, no.95. 


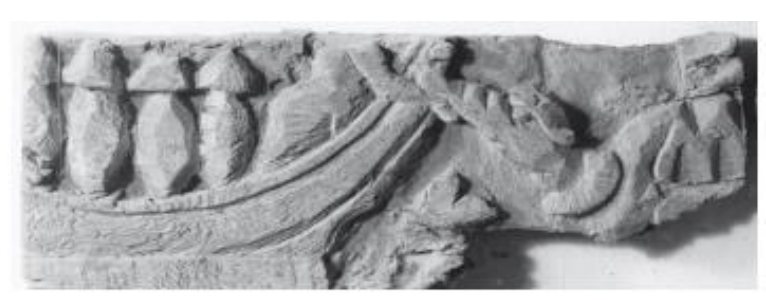

Fig.29. Wooden relief representing transporting amphoras by boat, $4^{\text {th }}$ Century, Coptic Museum 4876.

After: L. Torok, Transfigurations of Hellenism, Boston, Fig.88.

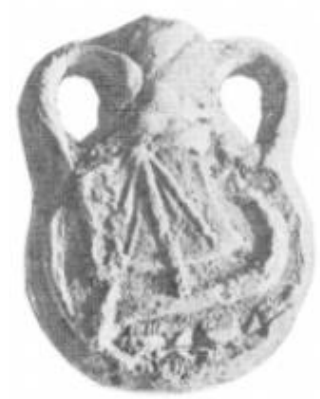

Fig.30: Terracotta pilgrim flask with sailing ship (Abu Mena, sixth-seventh century After: G. Vikan, Byzantine Pilgrimage Art, Dumbarton Oaks Trustees for Harvard University Washington, 1982, Fig.11.

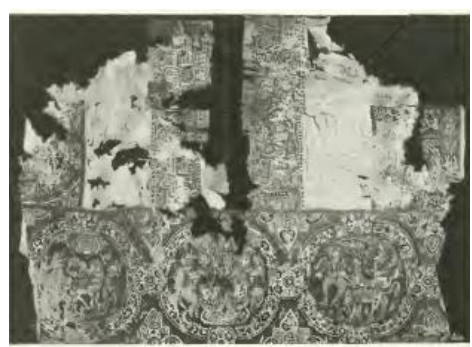

Fig.31: Boats on a portion of linen tunic, preserved in Victoria and Albert Museum, from Egypt, unrecorded provenance, $6^{\text {th }} / 7^{\text {th }}$ Century. After: A.F. Kendrick, Victoria and Albert Museum, Catalogue of Textiles from the Burying Grounds in Egypt, Coptic period, Vol III, 1922, p. 10, 11, pl. VI, no. 626.

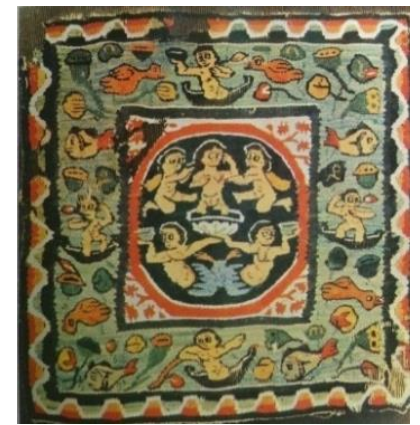

Fig. 32: Square panel of textile, preserved in Louvre Museum, $5^{\text {th }}$ century A.D. After: W. Volbach, Early Decorative Textiles, p. 12. 


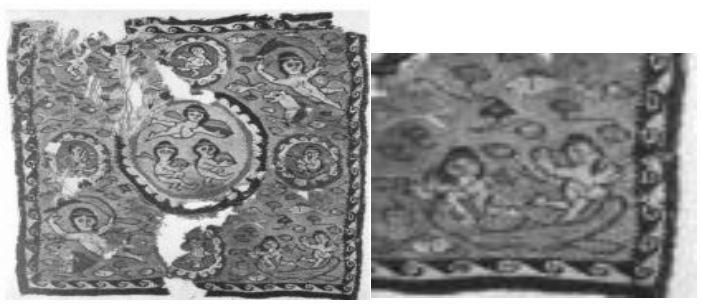

Fig.33: Square piece of tapestry, with detailed scene of the two children in the boat, the piece exhibited at the Brooklyn Museum no. 222, Egypt unrecorded provenance, $6^{\text {th }}$ Century.

\section{Bibliography}

After: Pagan and Christian Egypt, no. 222.

- Agnese, G., Ancient Egypt Art and Architecture of the pharaohs, New York, 2006.

- Altenmüller, H., "Funerary Boats and Boat Pits of the Old Kingdom." In Filip Coppens, ed. Abusir and Saqqara in the year 2001. Proceedings of the Symposium (Prague, Sept $25^{\text {th }}-27^{\text {th }}, 2001$ ), No. 3, Oriental Institute, Academy of Sciences of the Czech Republic, Prague, 2002.

- Anwar, M., "L'etude du patrimoine Copte a travers les phenomenes cosmiques dans l'art Copte", BSAC, Tome LVII, Le caire, 2018.

- Atalla, N., Coptic Art, Vol II, Cairo, 1989.

- Badawy, A., L'art Copte, les influences Egyptiennes, Preface par E. Driton, Le Caire, 1949.

- ----------, Coptic Art and Archeology, the Art of the Christian Egyptians from the Late Antique to Middle Ages, Mit Press, Cambridge, Massaclusette, London and England, 1978.

- Benazeth D., "les Coutumes Funérairess", L' art Copte en Égypte 2000 ans de Christianisme, Exposition présentée à 1'Institut du monde arabe, Paris, Gallimard, Paris, 2000.

- Budge, W., An Egyptian Hieroglyphic Dictionary, Vol 2, Horrisons and sons, London, 1920.

- Bleeker, J., Egyptian Festival Enactments of Religious Renewal, Leiden, Brill, 1967.

- Case, H., and Payne, J., "Tomb 100: The Decorated Tomb at Hierakonpolis", JEA, Vol. 48, Dec. 1962.

- Clèdat, M., "Le Monastère et la Nécropole de Baouit", MIFAO, Le Caire, 1916.

- -----------, "Le Monastère et la Nécropole de Baouit”, MIFAO, Le Caire, 1904.

- Creasman, P., Vining, B., Koepick S. and Doyle, N., "An Exploratory Geophysical Survey at the Pyramid Complex of Senwosret III at Dahshur", the International Journal of Nautical Archaeology (2009).

- Crum, M., Catalogue général des antiquités du musée du Caire, Coptic monuments, Le Caire, 1902.

- Dalton, O., Catalogue of Early Christian Antiquities and Objects from Christian East, London, 1901. 
- Der Vliet, J., Places of Passage, the Christian Epigraphy of the Western Oases with a Focus on the Kharga Oasis: Christianity and Monasticism in Alexandria and the Egyptian Deserts, (ed.) G. Gabra, Cairo, 2020.

- Diehl, C., L'art Chrétien primitive et l'art Byzantine, Paris, 1929.

- Duthuit, G., La sculpture Copte, Paris, 1931.

- Du bourguet, P., "Nereids; Mythological Subjects in Coptic Art", Coptic Encyclopedia, vol. 6, Atiya, A., (ed.), New York, 1991.

- ---------, "Nilotic scenes; Mythological Subjects in Coptic Art", Coptic Encyclopedia, vol.6, Atiya, A., (ed.), New York, 1991.

- ---------, The Art of the Copts, Paris, 1971.

- -----------, L'art Copte, Paris, 1968.

-

- El-Yahky, F., "Clarifications on the Gerzean Boat Scenes", BIFAO 85(1985).

- El Gendi, Sh., "Woodwork from the Coptic Museum displayed in the Antiquities Museum of the Library of Alexandria", BSAC, tome 58, Le Caire, 2019.

- El Mahdy, A., El Bassiiouny, K., and El Weshahy, M., "Scenes of the Goddess Amounet in the Temple of Medinet Habu", JAAUTH (15), 2018.

- Emery, W., Archaic Egypt, London, 1961.

- Erman, A., Wörterbuch Der Aegyptischen Sprache, Vol IV, Leipzig, 1982.

- Fakhry, A., the Necropolis of El- Bagawat in Kharga Oasis, 1951.

- Faulkner, R., A Concise Dictionary of Middle Egyptian, Oxford University Press, Oxford, 1962.

- ----------, Egyptian Grammar Being an Introduction to the Study of Hieroglyphs, $3^{\text {rd }}$ edition, Griffith Institute, Oxford, 1957.

- Gardiner, A., Egyptian Grammar, $3^{\text {rd }}$ edition, London, 1973.

- Gabra, G., Cairo the Coptic Museum and Old Churches, Cairo, 1993.

- --------- and Krauss, M.E., the Treasures of Coptic Art in the Coptic Museum and Churches of Old Cairo, the American University in Cairo Press, 2006.

- Goehring, J., New Fronteries in Pachomian Studies; the Roots of Egyptian Christianity, Pearson B.A., and Goehring J.E., (ed.), Fortress Press, New York, 1986.

- Hooper,F., Funerary Stelae from Kom Abou Billou, Kelsey Museum of Archaeology, 1961.

- Habib, R., Everyday Life from Coptic Antiquities, Mahaba bookshop.

- Hawass, Z., Hidden Treasures of the Egyptian Museum, the American University in Cairo Press, Cairo, 2002.

- James, P., Pyramid, New York, 1994.

- Isler, M., Sticks, Stones and Shadows; Building the Egyptian Pyramids, University of Oklahoma Press, 2001.

- Kaufmann, C., Handbuch der Christlichen Archaologie, Paderborn, 1922.

- ---------- C., Handbuch der Christlichen Archaologie, Paderborn, 1905.

- Kendrick, A., Victoria and Albert Museum, Catalogue of Textiles from the Burying Grounds in Egypt, Coptic Period, vol III, 1922. 
- Maspero, M., et Weit, G., Matériaux pour Servir à la Géographie de Egypt, MIFAO 36, Le Caire, 1919.

- Minaglou, G., Architecture at al Bagawat Cemetery: Christianity and monasticism in Alexandria and the Egyptian deserts, G. Gabra (ed.), Cairo, 2020.

- Monderson, F., Hatshepsuts Temple at Deir El Bahari, Bloomington, 2007.

- Nelson, H., Medinet Habu, the University of Chicago Press, Chicago, 1929.

- --------, Madinet Habu, Earlier Historical Records of Ramses III, vol. I, the university of Chicago press, Chicago, 1930.

- O' Corner. D., Abydos, Egypt's First Pharaohs and Cult of Osiris, AUC Press, 2009.

- Omran, W., "Transporting the Deceased by the Wheeled Cart in the Greco-Roman Tombs", JAAUTH, Vol.17, No2, (2019).

- Quibelle, J., and Green, F., Hierakonpolis, Part II, London, 1902.

- -------, Excavation at Saqqara (1907-1908), Le Caire, 1909.

- Siliotti, A., Guide to the Valley of the Kings, New York, 1997.

- Souli, S., Greek Mythology, Athens, 1995.

- Strouhal, E., Life of the Ancient Egyptians, University of Oklahoma Press, London, 1992.

- Tassie, G., "Hair in Egypt", Hair Styling Technology and Techniques used in Ancient Egypt Encyclopedia of the History of Science, Technology and Medicine in Nonwestern Cultures, H. Selin (ed.), 2008.

- Torok. L., Egypt After the Pharaohs; Treasures of Coptic Art from Egyptian Collections, Museum of Fine Art, Budapest, 2005.

- ----------, Transfigurations of Hellenism, Boston, 2005.

- Uzukwu, E., Worship as Body Language, the Liturgical Press, 1997.

- Vandier, J., Manuel d'archeologie Egyptienne, tom I, Les époques de formation, Paris, 1952.

- -Volbach, W., Early Decorative Textiles, Paul Hamlyn, 1969.

- Ward, Ch., Boatbuilding, and its social context in early Egypt: Interpretations from the First Dynasty Boat-Grave Cemetery at Abydos, 2006.

- ------, "Ships and Shipbuilding", OEAE, Vol.3 (2001).

- Wegner, J., "Abydos", The Oxford Encyclopedia of Ancient Egypt, D.B. Redford (ed.), Vol I, Oxford University Press, New York, 2001.

- ---------, “A Royal Boat Burial and Watercraft Tableau of Egypt's $12^{\text {th }}$ Dynasty (c.1850 BCE) at South Abydos", The International Journal of Nautical Archaeology, no. 46, 2017.

- A Basic Coptic Dictionary, Alphabetum Lactobiatarum, (ed.) Hermit of the Hermits of saint Bruno, St. Mary's Hermitage Press, 2014.

- Pagan and Christian Egypt Egyptian Art from the First to the Tenth Century A.D, Exhibited at the Brooklyn Museum by the Department of Ancient Art Jan23-March 9/1941, Brooklyn Institute of Arts and Sciences, 1974. 


\section{المراجع العربية والمعربة \\ - - - ابراهيم يوسف الثتله، جزور الحضارة الهصرية، هيئة الأثار المصرية، القاهرة. - - احمد فخري، الأهرامات المصرية، مكتبة الانجلو المصرية، 1963.} لـ، الصحراء المصرية، جبانة البجوات في الواحة الخارجة، هيئة الاثار المصرية، القاهرة،

- - ب.كوملان، الأساطير الإغريقية و الرومانية، ترجمة احد رضا، الهيئة العامة للكتاب، القاهرة، 1992. - - دومينيك بينازيث، "التقاليد الجنائزية"، الفن القبطي 2000 عام من الإنية المسيحية في مصر ، الهيئة المصرية

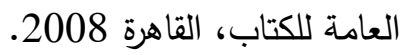

- - موفف حبيب، الاثر الدصري القديم في الفن القبطي، مكتبة المحبة.

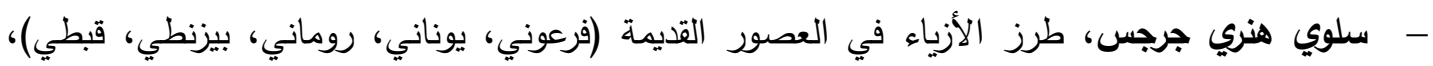

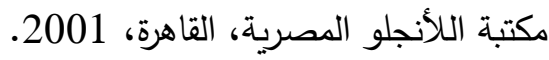
- عادل فخري صادق، "النيل ومكانته في الحقبة القبطية"، راكوتي، السنة الاولي العدد الثالث سبتمبر 2004، القاهرة. - - 2004

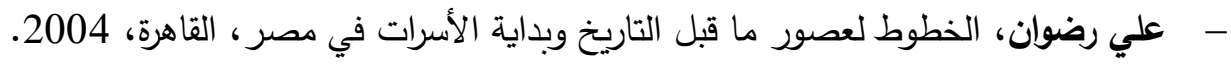
- - عزت زكي حامد قادوس ومحمد عبد الفتاح السيد، الأثار القبطية والبيزنطية، الإنكندرية، 2002 .

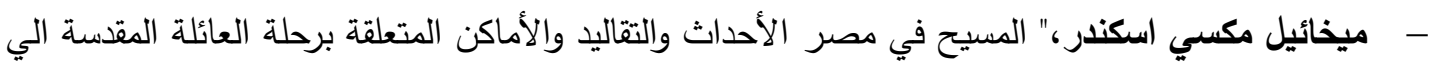

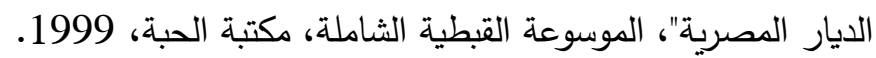

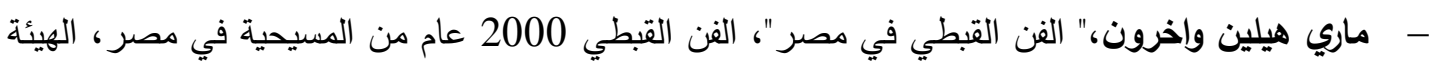

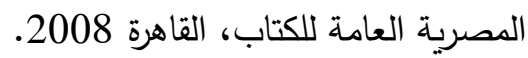
- - محمد علي، موسوعة اقاليم مصر الفرعونية قنا- سوهاج، القاهرة، 2016.

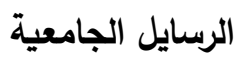

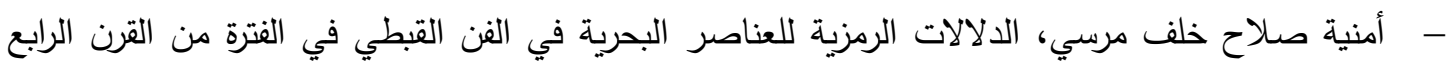

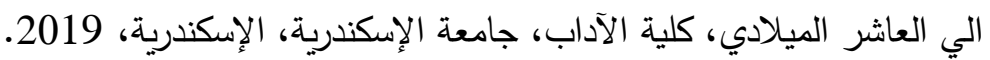
- ممال هيرمينا، تصوير المناظر الدينية والرمزية في الفن القبطي، رسالة دكتوراة، كلية الاثار جامعة القاهرة، 2011

- دعاء محمد بهي الدين، الرمزية ودلالاتها في الفن القبطي، رسالة ماجستير، جامعة الإسكندرية، كلية

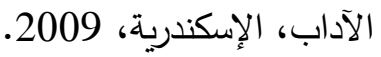

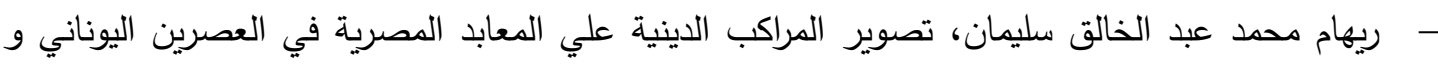
الروماني، رسالة ماجستير، كلية السياحة والفنادق، الإسكندرية، 2019.

\section{Net Sites:}

https://collections.louvre.fr/ark:/53355/c1010007467

https://exhibitions.kelsey.lsa.umich.edu/galleries/Exhibits/PortalsToEternity/21188.html; https://smb.museum-digital.de/singleimage.php?resourcenr=163640 https://coptic-dictionary.org/ 
مجلة اتحاد الجامعات العربية للسياحة والضيافة

\section{(JAAUTH)}

المجلد 20، العدد 4، (2021)، ص صل 124-158.

http://jaauth.journals.ekb.eg الموقع الإكتروني، العد

تمثيل القوارب في الفن البيزنطي

سارة حليم

مفيد الوشاحي

قسم الإرشاد السياحي، كلية السياحة والفنادق، جامعة قناة السويس

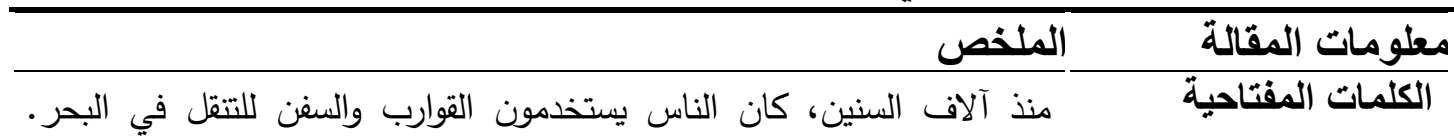

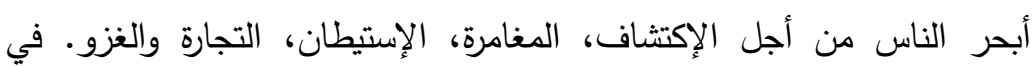

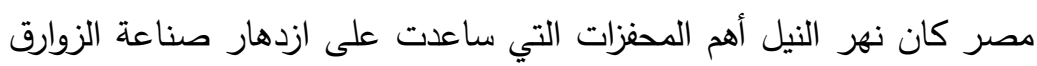

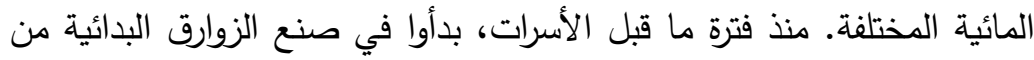

الفن القبطي؛ البيزنطي؛

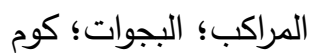

أبو بيلو.

نبات البردي، والتي سرعان ما تطورت الي المراكب الخشبية وسفن النقل

الضخمة، ومن ثم اخذوا يمثلونها على الصخور والفخار والجدران، ووصل

اهتمامهم بالقوارب إلى دفنها. ازدادت أهمية القوارب، وأصبحت صناعتها أكثر

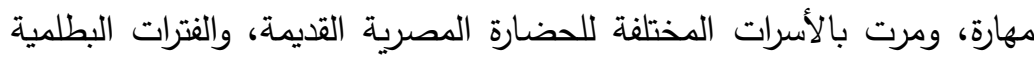

واليونانية والرومانية، حتى وصلت إلى الفترة البيزنطية التي اكتسب فيها تمثيل

(JAAUTH)

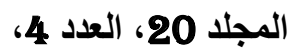

(2021)

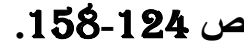

القارب المزيد من الرمزية بما يتناسب مع الديانة المسيحية الجديدة. يهدف هذا

البحث إلى تركيز الضوء على القوارب واستخداماتها من عصور ما قبل

الأسرات حتى الفترات البيزنطية، تحليل مشاهد مختلفة تمثل القوارب خلال هذه

الفترة، تتبع تطور المشاهد التي تمثل القوارب في الفن البيزنطي، وتحديد رمزية

القارب في الفن القبطي. 